\title{
IDEOLOGÍA POLÍTICA Y CRÓNICAS MONÁSTICAS: LA CONCEPCIÓN CLUNIACENSE DE LA REALEZA EN LA ESPAÑA DEL SIGLO XII ${ }^{1}$.
}

\author{
MANuel Alejandro Rodríguez de la PeÑa \\ Universidad Autónoma de Madrid
}

\begin{abstract}
SUMARIO
I. Introducción.- II. La línea historiográfica cluniacense en la Francia del siglo XI: precedentes ideológicos de la cronística cluniacense hispana.- III. El contexto ideológico-historiográfico de raigambre hispana: la contraposición con la mentalidad cronística de los monjes negros.- IV. La Historia Roderici ¿primera crónica del ciclo cluniacense?.- V. El discurso histórico filocluniacense de Gerardo de Beauvais en la Historia Compostelana.- VI. La Chronica Adefonsi Imperatoris: máximo exponente hispánico del modelo cluniacense de Realeza.- VII. El castellanismo filonobiliario de la Chronica Naierense.- VIII. Conclusión.
\end{abstract}

Fortes reges tyranni vocabantur...

SAN ISIDORO DE SEVILlA, Etimologías, IX, 3.

${ }^{1}$ La realización de este trabajo ha sido posible gracias a una beca de la Fundación Caja de Madrid. Quiero también agradecer los sabios consejos de mi director de tesis, Carlos de Ayala Martínez, así como la inestimable ayuda que me han prestado en esta investigación los medievalistas Juan Parral Puerta, Philippe Josserand y Mario Huete Fudio. Asimismo hay que señalar que esta investigación se inserta en el marco más amplio de un exhaustivo análisis del concepto de Realeza en la Castilla de los siglos XI al XIII, una investigación que presta especial atención al paradigma político de los reyes sabios. Por último, last but not least, me gustaría agradecer la desinteresada ayuda prestada por el profesor José Manuel Nieto Soria para la publicación de este artículo.

"Anuario de Estudios Medievales", 30/2 (2000) 


\section{INTRODUCCIÓN}

Este trabajo pretende llenar, de alguna forma, un vacío. Un vacío historiográfico, ello es cierto, pero que ha acabado por convertirse en un tópico aceptado, un lugar común no discutido ni reflexionado debido a su propia índole vacua. Este vacío al que aludimos se ha postulado entre la historiografía al confundirse las densas neblinas del pensamiento político castellano del siglo XII con una virtual ausencia de materia analizable. Así lo constató Wilhelm Berges al dar un repaso a la producción especular europea en su ya clásico trabajo, una obra de referencia que no por añeja ha perdido su valor. De esta forma, cuando se acerca uno al sistemático catálogo de Berges (que viene a ser el who is who de los specula principum del Occidente medieval), sólo descubre dos tardíos ítems hispánicos entre la profusión de nombres como Juan de Salisbury, Pedro de Blois, Godofredo de Viterbo, Gerardo de Gales, Vicente de Beauvais o Helinando de Froidmont.

Son estos dos ítems el Libro de los Doze Sabios y el Libro de Saviesa, relacionados respectivamente con Fernando III de Castilla y Jaime I de Aragón ${ }^{2}$. Dos espejos de príncipes que rozan ya la mitad del siglo XIII (1237 y 1246 son las fechas habitualmente otorgadas a su redacción). Y, por supuesto, si nos ceñimos estrictamente al siglo XII hispánico, el vacío en el catálogo es absoluto. Un resultado bien magro que no se corresponde con lo que sería de esperar. Algo que no es achacable, ni mucho menos, a una falta de erudición por parte del investigador germano ${ }^{3}$.

Una ausencia tanto o más inexplicable cuando, casi de inmediato, como un súbito fogonazo, surge en el siglo XIII ante nuestra mirada la luminosa y rotunda teorización política de Alfonso X el Sabio, precedida de la rica historiografía latina desarrollada por Rodrigo Jiménez de Rada, Lucas

${ }^{2}$ Wilhelm Berges, Die Fürstenspiegel des hohen und späten Mittelalters, "M. G. H. Schriften”, 2 (1938), pp. 299-301. Berges considera al Libro de los Doze Sabios como el primer speculum principis castellano. En nuestra opinión ese honor le correspondería al Libro de Alexandre, algo que intentaremos demostrar en un ulterior trabajo.

${ }^{3}$ En efecto, es de agradecer que, al menos, incluyera en su repertorio tratados políticos españoles (don Juan Manuel también atrajo su atención) dado que la mayor parte de las obras generales europeas sobre la cuestión ignoraban (y aún ignoran en muchos casos) el acervo del pensamiento político medieval hispano como algo marginal o simplemente inexistente. 
de Tuy y Juan de Osma, cuyo pensamiento político era ya sin duda puntero en el conjunto de la publicística europea del momento ${ }^{4}$. Utilizando un adagio escolástico podríamos decir: ex nihil nihil, de la Nada no puede surgir nada. Esto es, el esplendor alfonsí, en éste como en tantos otros campos, tuvo necesariamente que tener una fundamentación en el periodo que le precedió.

Aún más misterioso es este vacío si nos asomamos al estallido especular que se vivió a partir de finales del siglo XII en los reinos de Francia e Inglaterra, así como en el Sacro Imperio Germánico (en particular, en lo que toca a sus despiertos súbditos italianos), una proliferación de espejos de príncipes que, sin razón aparente, no tendría paralelo en esos mismos años en los reinos españoles.

Por desgracia, el espectacular desarrollo de la investigación española sobre ideología política medieval en estos últimos años no ha repercutido aún en un análisis del siglo XII y apenas algo se ha hecho en lo que toca a la primera mitad del siglo XIII. Así, el más brillante de cuantos hoy investigan teoría política medieval en España, José Manuel Nieto Soria, ha circunscrito su labor de análisis al periodo posterior al año en que Alfonso X subió al trono ${ }^{5}$. Y como él muchos otros historiadores, absorbidos por la riqueza de las fuentes que la Baja Edad Media les ofrece.

Ahora bien, a la hora de analizar la literatura política del propio siglo $\mathrm{XV}$, Alan Deyermond ha escrito algo que, ciertamente, viene muy al caso: "No debe sorprendernos que las primeras manifestaciones de la ideología del Estado en la literatura española se encuentren mucho antes del siglo XV. Se encuentran en la literatura vernácula, de hecho - si hacemos excepción de unos posibles matices en el Auto de los reyes magos- hacia 1207, en el Cantar de Mio Cid. Poco después se nota en algunos aspectos de la historiografía hispanolatina, sobre todo en De Rebus Hispaniae (1243) de Rodrigo Jiménez de Rada"6. Como veremos, Deyermond, a pesar de vislumbrar el

${ }^{4} \mathrm{El}$ trabajo más completo y erudito sobre la historiografía medieval hispana es, sin duda, el de Peter LINEHAN, History and the Historians of Medieval Spain, Oxford, 1993. No obstante, esta magna obra (de obligada consulta) deja algunas lagunas por rellenar, como, por ejemplo, en relación al tema que nos ocupa.

${ }^{5}$ Vid. José Manuel NIETO SORIA, Fundamentos ideológicos del poder real en Castilla (siglos XIII al XVI), Madrid, 1988. Es esta una obra de referencia obligada para cualquiera que se interese por la ideología política de la Castilla medieval.

${ }^{6}$ Alan DEYERMOND, La ideología del Estado moderno en la literatura española del siglo XV, "Realidad e imágenes del poder", ed. A. RuCQUOI, Valladolid, 1988, p. 171. 
problema se queda bastante corto en su diagnóstico. Estos aspectos de la historiografia hispanolatina que él menciona se aparecen ante nosotros cargados de una inesperada frondosidad ideológica y resultan ser mucho más tempranos que el De Rebus Hispaniae.

Entonces, ¿nos encontramos ante un ejemplo de atraso, ya sea en lo cultural o en lo político, de las sociedades medievales hispánicas? Dadas estas premisas, creemos que, antes que seguir sosteniendo la existencia de un vacío en el campo de la teoría política en los reinos de León y Castilla a lo largo del siglo XII, resulta bastante más acertado reiniciar la búsqueda con mayor atención, esto es, emprender una audaz cacería de unos vestigios textuales especulares que la propia lógica histórica nos dice que debieron tener realidad. La clave de la cuestión está, y esto acaso pueda parecer obvio, en el replanteamiento de los criterios de búsqueda, dado que con los vectores anteriores apenas se identificaron un par de textos dignos de interés.

Es aquí donde conviene adoptar la mayor amplitud de miras posible. No podemos seguir encorsetados en unas estrechas perspectivas, relativamente imbuidas de presentismo, que exigen a los textos políticos medievales una autoidentificación palmaria como tales. Esta reflexión, que se podría extender a otros campos de la historia de las mentalidades, no por repetida en los últimos tiempos deja de ser necesaria para la cuestión que nos ocupa. Pese a la revisión historiográfica impulsada en el campo de la historia política por la Escuela de Annales en Francia y por las siempre fecundas y sesudas escuelas alemanas, muchos investigadores aún se resisten a abrir su mirada a otras disciplinas como la Literatura, la Filosofía o la Didáctica a la hora de seguirle el rastro al pensamiento político medieval.

Parecen olvidar un hecho fundamental: los autores medievales, imbuidos de un sano universalismo disciplinar, no hacían distinción alguna entre los diversos campos del saber a la hora de deslizar reflexiones que hoy catalogamos como políticas. Todo texto medieval es susceptible de contener pensamiento político, precisamente debido al hecho de que ningún texto medieval se presenta a sí mismo como abiertamente político. Ni siquiera los espejos de príncipes son sensu stricto tratados "políticos" (al menos en su actual acepción o en la que pudieron darle ya en la Edad Moderna Maquiavelo, Jean Bodin o Johannes Althusius).

Son más bien una mezcla heterogénea de discursos históricos y consejos morales, filosóficos, científicos, religiosos, sanitarios, económicos y políticos, cohesionados entre sí por una argamasa didáctica y enciclopedista 
que impide que aparezcan a los ojos del lector medieval como disgresiones sin sentido $^{7}$. Y es que fue un espíritu esencialmente didáctico el que los animó, un Ideal sapiencial, esto es, una intención consciente de dar instrucción a los gobernantes. Recuérdese el adagio rex illitteratus est quasi asinus coronatus ${ }^{8}$. Sintomática es, en este sentido, la facilidad con la que se intercambiaban los términos para designar al manual pedagógico propiamente dicho y al tratado especular dirigido a un lector principesco: Instructio, Educatio, Disciplina, Eruditio, Speculum, Doctrinal, Miroir, Enseignement...

Instruir, enseñar a los príncipes, no únicamente sobre los arcanos del poder, sino también, y quizá principalmente, en los entresijos de la Sabiduría, entendida ésta desde una óptica a un tiempo moral (prudentia), mística (Sapientia) y cognitiva (eruditio). Ciertamente, estos tratados van más allá de la definición al uso de catecismos político-morales, pues no se limitan a ser meros catálogos de vicios y virtudes o simples tratados de cortesía palaciana. No, su temática es, en muchas ocasiones, bastante más ambiciosa a fuer de universalista.

En consecuencia, es evidente que toda pretensión de encerrar al género especular en unos límites disciplinares precisos parece condenado al fracaso. Todo speculum principis participa de al menos tres o cuatro campos

\footnotetext{
${ }^{7}$ En este sentido, Pierre RICHÉ ha deslizado observaciones interesantes en su trabajo Sources pédagogiques et traités d éducation, "Les entrées dans la vie. Initiations et apprentissages" (Actes du XIIle Congrès de la Société des Historiens médiévistes de l'Enseignement Supérieur public), Nancy, 1981, pp. 15-29.

${ }^{8}$ Por no abrumar al lector con un exceso de bibliografía señalaremos apenas unas cuantas obras de referencia en este sentido. Wilhelm BERGES, en su mencionado estudio sobre los espejos de príncipes (Die Fürstenspiegel, p. 66), acuñó la expresión Ideal des gelehrtenkönigs para hacer referencia a la aspiración a la sabiduría de los reyes imbuidos de los ideales escolásticos del renacimiento del siglo XII. Herbert GRUNDMANN (Sacerdotium-Regnum-Studium. Zur Wertung der Wissenschaft im 13. Jahrhundert, "Archiv für Kulturgeschichte", 34 (1951), Ernst R. CURTIUS (Europaische Literatur und lateinisches Mittelalter, Berna, 1948, ed. esp. Literatura europea y Edad Media latina, México, 1955), Jacques LE GoFF (Les Universités et les pouvoirs publics au Moyen Age et à la Renaissance, "Pour un autre Moyen Âge", París, 1978, ed. esp. en Tiempo, trabajo y cultura en el Occidente medieval, Madrid, 1983) y Alexander MURRAY (Reason and Society in the Middle Ages, Oxford, 1978, ed. esp. Razón y Sociedad en la Edad Media, Madrid, 1982) han abordado esta cuestión desde diferentes ópticas. En el ámbito español ha sido José Antonio MARAVALl quien mayor atención ha prestado a este aspecto (vid. El intelectual y el poder. Arranque de una actitud histórica, "Cuadernos del Idioma", 3 (1965), pp. 5-25; Los hombres de saber o letrados y su conciencia estamental, "Revista de Estudios Políticos" 70 (1953) y La concepción del saber en la sociedad tradicional "Estudios", op. cit., pp. 203-259). Más recientemente, en torno a la noción de Ideal sapiencial, se puede consultar nuestro trabajo Imago Sapientiae: los orígenes del Ideal sapiencial medieval, "Medievalismo", 7, 1997, así como nuestra memoria de licenciatura El nacimiento del Ideal sapiencial medieval: la función política de la Sabiduría en la concepción carolingia de la Realeza, Universidad Autónoma de Madrid, 1997 (en prensa).
} 
del saber diferentes a la ciencia del buen gobierno. Del mismo modo, podemos hallar características abiertamente especulares en obras literarias, filosóficas y didácticas de diversa índole. Ya desde los brumosos orígenes de la cultura plenomedieval, en los "siglos de hierro" postcarolingios, se concebía en los monasterios benedictinos que toda obra narrativa era unsermo o una lectio moralizante, es decir, un ejercicio de eloquentia y no únicamente de scientia ${ }^{9}$.

Un espíritu adoctrinador que permaneció, aunque algo más secularizado y alejado de los monasterios, tras el despegue historiográfico enmarcado en el renacimiento del siglo XII. Y es que, como Boehm y Smalley han señalado, la escolástica del siglo XII ensalzaría a la Historia convirtiéndola en la síntesis de las tres Artes del Trivium $^{10}$, yendo de la mano el florecimiento del género cronístico y el de los espejos de príncipes. Carmen Orcástegui ha definido con acierto este fenómeno: "La historia es una actividad esencial del espíritu en estos siglos, pues enraíza a los hombres y a las instituciones confrontándolos con el ideal de los orígenes... la literatura histórica entronca con el humanismo literario propio de la época"11.

No es de extrañar pues, tal y como nos indica el indiscutible magisterio en este campo del profesor francés Bernard Guenée ${ }^{12}$, que la

${ }^{9}$ Vid. P. Rousset, La conception de l'histoire à l'époque féodale, "Mélanges d'histoire du Moyen Âge", ed. L. Halphen, París, 1951, pp. 623-633. Esto se puede comprobar en una de las primeras obras cronísticas de carácter especular que alumbró el pleno Medievo, la Vida de Roberto el Piadoso del monje Helgaud de Fleury (vid. R.H. BAUTIER, L'Epitoma Vita Rotberti Pii du moine Helgaud, "Académie des Inscriptions et Belles-Lettres" (1963), p. 364 y ss.).

${ }^{10}$ L. BOEHM, Der wissenschaftstheoretische Ort der Historia im Mittlalter: Die Geschichte auf dem Wege zur Geschichtswissenschaft, "Speculum Historiale: Geschichte im Spiegel von Geschichtsschreibung und Geschichtsdeutung", ed. C. Brauer, Munich, 1965, p. 665 y B. SMALLEY, Historians in the Middle Ages, Londres, 1979, p. 179; vid. también A. BORST, Geschichte an mittelalterlichen Universitäten, Constanza, 1969 y H. WOLTER, Geschichtliche Bildung im Rahmen der Artes Liberales, "Artes Liberales. Von der Antiken Bildung zur Wissenschaft des Mittelalters", ed. J. Koch, Leyden, 1959, pp. 50-83. No obstante, para Bernard GUENÉE la historia ocupó siempre un lugar secundario en la universidad medieval (Histoire et culture historique, París, 1980, p. 35). 137.

${ }^{11}$ Carmen OrCÁSTEGUi; Esteban SARASA, La Historia en la Edad Media, Madrid, 1991, p.

${ }^{12}$ Bernard GUENÉE, Histoire et culture historique, op. cit., p. 332; vid. también su trabajo $L$ 'histoire entre l'eloquence et la science. Quelques remarques sur le prologue de Guillaume de Malmesbury a ses Gesta rerum Anglorum, "Académie des Inscriptions et Bellles-Lettres" (1982), pp. 357-370. En torno a la historiografía latina del siglo XII resulta muy interesante el trabajo ya añejo de J. SPÖRL (Grundformen der hochmittelalterlichen Geschichtsanschauung: Studien zum Weltbild der Geschichtsschreiber des 12. Jahrhunderts, Munich, 1935). En lo que respecta a los cantares de gesta muy tempranamente se adelantó esta idea (vid. L. GAUTIER, L'idée politique 
cronística haya demostrado ser un auténtico filón para el buscador de ideas políticas medievales ${ }^{13}$. Y es que, algunos años antes que el propio Guenée, el investigador alemán Helmut Beumann había avanzado esta idea en un artículo en el que proponía la utilización sistemática de la cronística medieval como fuente primordial para estudiar la concepción que en ese tiempo se tenía de la Realeza ${ }^{14}$.

También en esta línea, Inés Fernández-Ordóñez ha destacado la relevancia que adquieren los señores del Mundo para estos autores, lo cual se debe a su papel de magistri principum, de ejemplo para los futuros príncipes. En efecto, el elenco de vidas de monarcas gloriosos constituía una fuente primordial de material a la hora de escribir un manual de formación política para los príncipes y también, señala Inés Fernández-Ordónez, para los pueblos que habían de ser adoctrinados en la veneración hacia la Realeza ${ }^{15}$. Si bien en menor medida que Fernández-Ordóñez, también Carmen Orcástegui ha vislumbrado la importancia detentada por los aspectos edificantes inherentes a la imago regis transmitida por la historiografía medieval ${ }^{16}$.

En un reciente artículo, Leonardo Funes ponía el dedo en la llaga al recordarnos algo que los trabajos de Diego Catalán ya han probado en la práctica, esto es, que los aspectos discursivos de las crónicas medievales, en especial su ideología política, son hoy por hoy el aspecto fundamental de éstas, una vez superada tanto su aceptación acrítica cual si fueran documentos fidedignos, como la marginación a la que han sido sometidas por las corrientes historiográficas excesivamente amantes del documento y los

dans les chansons de geste, "Revue de questions historiques" (1869), pp. 79-114).

${ }^{13}$ Algo que ya han apuntado para el caso español, entre otros, Peter LINEHAN (vid. History and the Historians of Medieval Spain, op. cit., y Pseudo-historia y pseudo-liturgia en la obra alfonsina, "España y Europa: un pasado jurídico común", Murcia, 1985, pp. 259-274), Francisco RICO (vid. Alfonso X el Sabio y la General Estoria, Barcelona, 1984) e Inés FERNÁNDEZORDÓNEZ, La Historiografía alfonsi y post-alfonsí, "Cahiers de Linguistique Hispanique Médiévale", 18-19 (1993-1994), pp. 101-132.

${ }^{14} \mathrm{Vid}$. H. BEUMANN, Die Historiographie des Mittelalters als Quelle für Ideengeschichte des Königstums, "Ideengeschichtliche Studien zu Einhard und anderen Geschichtesschreibern des früheren Mittelalters", Darmstadt, 1969, pp. 40-79. p. 113

${ }^{15}$ Inés FERNÁNDEZ-ORDÓÑEZ, La Historiografía alfonsí y post-alfonsí en sus textos, art. cit.,

${ }^{16}$ Carmen ORCÁstegui; Esteban SARASA, La Historia en la Edad Media, op. cit., pp. 40-43. 
archivos ${ }^{17}$. Las crónicas, en tanto que monumentos discursivos, se perfilan, por consiguiente, como una fuente funda- mental para conocer la producción ideológica del periodo, particularmente en los siglos anteriores al florecimiento del género de los specula principum. Emilio Mitre ha encontrado una oportuna definición para este planteamiento. Utilizando una terminología medieval, ha descrito a la Historia en la Edad Media como una ancilla scientiae politicae. Una relación de sometimiento muy similar a la que mantenía la Filosofía medieval respecto de la Teología ${ }^{18}$.

Ahora bien, en lo que atañe a la estricta producción historiográfica hispana, Peter Linehan es bastante concluyente: los reinos de Castilla y León fueron hasta el año 1230 an under-developped area $^{19}$, en agudo contraste con la frenética actividad cronística de los monjes ingleses que él contrapone como ejemplo (también se podría aludir a la "edad de oro" de la historiografía francesa a lo largo del siglo XII). De la misma opinión es Carmen Orcástegui, quien apunta que "la historiografía española de estos siglos tiene escasa importancia en comparación con la coetánea europea tanto en calidad como en cantidad" ${ }^{\prime 2}$. Es ésta, por tanto, una de las claves de la escasa producción ideológica hispana en el siglo XII, dado que en este periodo, como hemos dicho, el género de los espejos de príncipes todavía no había calado en los reinos hispánicos.

Sin embargo, en nuestra opinión, la escasez de material analizable desde el punto de vista del pensamiento político no se debe tanto a la parquedad del género cronístico en el siglo XII (una parquedad matizable), sino al hecho de que, a diferencia de sus coetáneos ingleses, franceses e imperiales, los cronistas castellanos y leoneses del periodo no se ajustaron al perfil de clericos aulicos. Como ha señalado Nieto Soria, fueron los clérigos

${ }^{17}$ Vid. Leonardo FUNES, Las crónicas como objeto de estudio, "Revista de Poética Medieval", 1 (1997), pp. 123-144.

${ }^{18}$ Emilio MITRE, El Siglo alfonsí: cultura histórica y poder real en la Castilla del siglo XIII, "Alfonso X. Aportaciones de un Rey castellano a la construcción de Europa", ed. M. RODRÍGUEZ LLOPIS, Murcia, 1997, p. 102.

${ }^{19}$ Peter LINEHAN, On further Thought: Lucas of Tuy, Rodrigo of Toledo and the Alfonsine Histories, "Anuario de Estudios Medievales", 27 (1997), p. 415. Un completo y exhaustivo repertorio de la historiografía latina hispana anterior al siglo XIII lo tenemos en la obra de Mario HUETE, La historiografia latina medieval en la Península Ibérica (siglos VIII-XII), Universidad Autónoma de Madrid, 1997.

${ }^{20}$ Carmen ORCÁSTEgUI; Esteban SARASA, La Historia en la Edad Media, op. cit., p. 199. 
del Rey los principales artífices de la publicística política medieval hispana y europea $^{21}$, y en los reinos de Castilla y León hay que esperar a un Lucas de Tuy o un Rodrigo Jiménez de Rada para hallar a unos clérigos cronistas que se ajusten, en rigor, a esta figura del propagandista de la Realeza.

Efectivamente, en los autores de la la Chronica Naierense, la Historia Compostelana o la Chronica Adefonsi Imperatoris no descubrimos un perfil de clericus aulicus. Son, antes que nada, monjes o clérigos que escriben al servicio de unos intereses eclesiásticos (bien los de la sede compostelana, bien los de la Orden de Cluny): ad maiorem Dei gloriam. La gloria regia es aquí un asunto de interés menor. Ni siquiera en la obra de Arnaldo de Astorga, probable autor de la Chronica Adefonsi, obispo muy próximo al monarca biografiado, encontramos un paralelo historiográfico con un Otón de Freising o un Suger de Saint Denis. Como veremos al abordar el análisis de la Chronica Adefonsi Imperatoris, los intereses que priman en el discurso de la obra no son, ni mucho menos, los de la Realeza.

La explicación de las peculiaridades ideológicas de la cronística hispana del siglo XII se apoya en un único factor: el intenso papel cultural desempeñado por los monjes cluniacenses en este periodo. Efectivamente, a lo largo del siglo largo que transcurre entre el acceso al trono de Fernando I (año 1037) y la muerte del emperador Alfonso VII (año 1157), los monjes cluniacenses venidos de Borgoña van a obtener una influencia política e ideológica en los reinos de León y Castilla (a los que proporcionó todo una generación de obispos y consejeros aúlicos), que no tiene parangón en el resto de la Europa del momento, según concluye Marcélin Defourneaux ${ }^{22}$. Una influencia paralela al complejo y aún poco aclarado proceso de incorporación de formas feudales borgoñonas durante el reinado de Alfonso VI, un proceso que es definido por Defourneaux como una virtual colonisation féodale ${ }^{23}$.

${ }^{21}$ Vid. José Manuel NiETo SORIA, Les clercs du Roi et les origines de l'État moderne en Castille: propagande et légitimation (XIIIème-XVème siècles), "Journal of Medieval History", 18 (1992), pp. 297-318. $17-18$

${ }^{22}$ Marcélin DeFOURnEAUX, Les français en Espagne aux XIe et XIIe siècles, París, 1949, pp.

${ }^{23}$ M. Defourneaux, Les français en Espagne, op. cit., p. 230. 
Se puede decir que cuando el arzobispo Bernardo de Sedirac ${ }^{24}$ regresó hacia 1095 de su estancia en el concilio cruzado de Clermont acompañado de una nutrida comitiva de monjes y clérigos franceses, gentes tan honestas como letradas, se produjo, de alguna forma, el desembarco en los reinos hispánicos de una nueva intelligentsia que iba a sustituir al clero de tradición hispanomozárabe ${ }^{25}$. Estos clérigos franceses, incorporados al capítulo catedralicio toledano en un primer momento, van a copar la mayor parte de las dignidades episcopales en las décadas siguientes. De entre ellos destacaron Gerardo de Moissac (arzobispo de Braga), Pedro de Béziers (obispo de Osma), Pedro de Agen (obispo de Segovia), Jerónimo de Perigord (obispo de Valencia) y, finalmente, Raimundo, arzobispo de Toledo y fundador de la Escuela de Traductores de Toledo ${ }^{26}$.

En suma, el leif-motiv de este trabajo consiste en intentar sacar a la luz los elementos especulares (es decir, la imagen de la Realeza) contenidos en la cronística cluniacense hispana, identificarla en cuanto ciclo historiográfico ideológicamente coherente (en la medida en que esto es posible para el Medievo, una época en la cual no hay nunca líneas ideológicas férreas y monolíticas) y, finalmente, dilucidar cuáles eran los ejes en torno a los cuales se estructuraba su pensamiento político.

Estos ejes son dos arquetipos políticos de raíz isidoriana, el Rex tyrannus y el Rex iustus, que fueron aplicados por los cronistas cluniacenses de forma reiterada y consciente como epítetos definitorios a los soberanos que se quiere denigrar o ensalzar. Sin embargo, tal y como aparecen recogidos en el pensamiento cluniacense estos arquetipos habían perdido el contenido conceptual original del que les había dotado San Isidoro de Sevilla a partir de la herencia clásica ciceroniana. De acuerdo con su famoso adagio Rex a recte regendo que definiría al Rex iustus, Isidoro definía a los "tiranos" en sus Etimologías como a "pessimos atque improbos reges, luxuriosae dominationis cupiditatem et crudelissimam dominationem in populis exercentes" ${ }^{27}$. Por tanto, la noción isidoriana de tiranía se apoyaba en la condición de Rex

\footnotetext{
${ }^{24}$ Monje cluniacense francés, abad de Sahagún, convertido en el primer arzobispo de la Toledo reconquistada por Alfonso VI.

${ }^{25} \mathrm{M}$. DefourneauX, Les français en Espagne, op. cit., p. 35.

${ }^{26} \mathrm{M}$. DEFOURnEAUX, Les français en Espagne, op. cit., pp. 35-37.

${ }^{27}$ SAN ISIDORO DE SEVILlA, Etymologiae, IX, c. III, 18-20 (ed. J.P. Migne, Patrologia Latina, 82, col. 342).
} 
iniustus, concepto que implicaría sobre todo el ejercicio de un gobierno opresivo sobre sus súbditos, esto es, una crudelissima dominatio. Es aquí el populus la víctima, el punto de referencia del tema tiránico.

Por contra, en la mentalidad política cluniacense, impregnada del espíritu de la Reforma gregoriana, se asimila el concepto de tiranía con el del Rex impius. Pero la impiedad regia a la que se alude no depende de la devoción religiosa personal del soberano sino que consiste, en general, en su anuencia o resistencia a los principios hierocráticos de la Reforma y, en particular, en sus relaciones con el Papado o el clero. De esta forma, el apelativo de tyrannus se va a aplicar independientemente del mal o buen gobierno del Rey, primando su sumisión a la tuitio eclesiástica. Y es que este fue este uno de los principales legados ideológicos de la fértil publicística política surgida al albur de la Querella de las Investiduras: la utilización propagandística del arquetipo tiránico como recurso literario destinado a debilitar la aureola carismática de la Realeza.

Curiosamente, este giro conceptual dado por los publicistas gregorianos al arquetipo tiránico supuso, de alguna forma, un retorno al sentido semántico original del término tal y como lo reseñaba el propio San Isidoro: fortes reges tyranni vocabantur ${ }^{28}$. En verdad, de eso se trataba. Son reges fortes quienes van a sufrir esta acusación a lo largo del siglo XII.

\section{LA LÍNEA HISTORIOGRÁFICA CLUNIACENSE EN LA FRANCIA DEL SIGLO XI: \\ PRECEDENTES IDEOLÓGICOS DE LA CRONISTICA CLUNIACENSE HISPANA}

Georges Duby llamó la atención en su obra magna, Los Tres Órdenes o lo Imaginario del Feudalismo, sobre la pugna ideológica que mantuvieron contra Cluny en la primera mitad del siglo XI obispos de tradición carolingia como Adalberón de Laon o Gerardo de Cambray. Los monjes negros habían sustituido a los obispos, les acusaba Adalberón, en la función sapiencial de aconsejar al Rey. En particular, el abad Odilón de Cluny es señalado como "usurpador" del lugar de los obispos, en tanto que clericos aulicos, junto al

\footnotetext{
${ }^{28}$ SAN ISIDORO DE SEVILla, Etymologiae, loc. cit.
} 
$\operatorname{Rey}^{29}$. Así pues, en el siglo XI había una conciencia en Francia de que los monjes habían usurpado el papel del clero secular en tanto que creadores de ideología. ¿Y qué pretendían en concreto los cluniacenses? El propio Duby nos responde escuetamente: monarquizar la condición de los nobles ${ }^{30}$. Lo cual, según denuncia Adalberón en su Carmen ad Rodbertum regem, suponía un debilitamiento de la posición de preeminencia política y moral de la Realeza.

En otro orden de cosas, pero que también afecta a la crisis de la clerecía aúlica en el siglo XI, Bernard Guenée advierte que, en torno al Año Mil, los cronistas desaparecen de los capítulos catedralicios del Occidente cristiano y se les empieza a encontrar únicamente en los scriptoria monásticos. Va a tener que transcurrir más de un siglo para que esta situación se invierta, ya en el marco del renacimiento del siglo XII. No obstante, si bien es cierto que, en general, el espíritu monástico benedictino fue muy proclive al cultivo de la historia, Guenée apunta que la espiritualidad cluniacense fue más bien reacia a este género, dado que les interesaban más aspectos como la maestría del estilo en lengua latina de los historiadores de la Antigüedad o la especulación sobre una teología de la historia, que el opus cronístico en sí mismo $^{31}$. De hecho, señala Guenée, el único historiador francés de obediencia estrictamente cluniacense del siglo XII fue Ricardo el Pictavense.

Aunque, por supuesto, la situación fue muy diferente en el siglo XI donde sí encontramos historiadores cluniacenses de la talla de Raúl Glaber, Ademar de Chabannes y Orderico Vitalis (este último a caballo entre los dos siglos), la verdad es que si bien es cierto que la mayor parte de los cronistas de este periodo fueron monjes benedictinos, muchos de entre los más destacados (como Sigeberto de Gembloux, Helgaud de Fleury, Roberto de Torigni o Guillermo de Jumiñges) no vistieron el hábito negro de Cluny, siendo cronistas laudatorios de la Realeza o incluso polemistas antigregorianos como Sigeberto. Lo cual dice mucho de esta cuestión si tenemos en cuenta la enorme preponderancia adquirida por la casa madre cluniacense en esos años.

\footnotetext{
${ }^{29}$ Georges DuBy, Les Trois Ordres ou l'imaginaire du féodalisme, París, 1978, ed. esp. Los Tres Órdenes o lo Imaginario del Feudalismo, Madrid, 1992, pp. 92-93.

${ }^{30} \mathrm{G}$. DuBy, Les Trois Ordres, op. cit., p. 93.

${ }^{31}$ B. GUENÉE, Histoire et culture historique, op. cit., p. 47; la situación no fue mucho mejor en los monasterios de obediencia cisterciense donde, según Guenée, el género histórico se limitó
} a vegetar (ibíd.). 
En todo caso, la opinión del historiador inglés Galbraith en el sentido de que los monjes que se dedicaban a elaborar crónicas eran los "fracasados" del monasterio parece fuera de lugar ${ }^{32}$.

Lo que sí es indudable es la escasa o nula conexión de los contados cronistas cluniacenses con la Realeza francesa. Resulta esclarecedor en este sentido comprobar como los dos grandes biografos de reyes franceses de este periodo son monjes que no pertenecían a la disciplina de Cluny sino a monasterios de tradición benedictina carolingia: Fleury y Saint Denis. Las vidas de Roberto el Piadoso y Luis VI el Gordo compuestas por Helgaud y Suger $^{33}$, constituyen monumentos literarios, casi hagiográficos, ad maiorem Regis gloriam en los que se pretende asentar una imagen carismática de la Realeza francesa, envuelta en una relación directa de patronazgo con ambos monasterios (ambos lugar de enterramiento de miembros de la dinastía capeta, aunque en distintos niveles). Así pues, las comunidades monásticas de Fleury y Saint Denis estaban interesadas en una línea ideológica que iba en un sentido opuesto al de la cluniacense.

Ciertamente, como parecen probar de forma fehaciente los trabajos de Dutton, France y Ortigues, los intereses del historiador más afamado de filiación cluniacense, el "monje calvo" Raúl Glaber, entraban más en el campo de lo teológico-especulativo que en el de la narración de los acontecimientos (res gestae) propiamente dicha. En opinión de Carmen Orcástegui, la obra de Glaber tiene más valor como una autobiografía en la que se expone su postura ante el milenarismo, el misticismo, la herejía o la superstición, ya que no constituye de ninguna manera una suma de conocimientos históricos. Además, cuando estos aparecen en su narración se circunscriben a la región de Borgoña y sus alrededores ${ }^{34}$.

De hecho, la principal aportación de sus Historiarum Libri Quinque (1030-1047) compuestos por encargo del abad Odilón de Cluny, es de índole teológica. Apoyándose en Máximo el Confesor, el monje cluniacense dividió el Cosmos en cuatro partes, lo que él llama divina Quaternitate. Esta división cuatripartita del Mundo se trasladaría al ámbito del devenir histórico, estableciendo Raúl Glaber una división de los tiempos en cuatro edades a las

${ }^{32}$ V.H. GALBRAITH, Historical Research in Medieval England, Londres, 1951, pp. 10-11.

${ }^{33}$ Vid. R.H. BAUTIER, L'Epitoma Vita Rotberti Pii du moine Helgaud, art. cit.

${ }^{34}$ C. ORCÁstegui; E. SARASA, La Historia en la Edad Media, op. cit., p. 142. 
que sucedería una Quinta Edad escatológica en la que se produciría el advenimiento de Cristo $^{35}$. Como se puede ver, esta especulación de resabios neoplatónicos no tiene nada que ver con lo que entendemos por una crónica.

Edmond Ortigues ha llamado la atención sobre un episodio de las Historias de Glaber que él considera el más significativo de la crónica desde el punto de vista de la ideología política. Cuando el monje cluniacense relata la coronación imperial en Roma (año 1014) de Enrique II por parte del papa Benedicto VIII, va a aprovechar para introducir una serie de imágenes de hondo significado político. Así, dentro de un esquema hierocrático de sometimiento de los bellatores (cuya cabeza es el emperador) a los oratores (cuya cabeza es el Pontífice), Raúl alude a las cuatro gemas del orbe (sphaira) de oro entregado por el Papa a Enrique II como insignia imperial, un orbe que sería una imago quaternitatis mundi (un modelo intelectual del mundo cuaternario de acorde con la visión teológica a la que hemos aludido) a la par que un documentum cuya función sería recordar al emperador dos cosas: 1) su potestad se restringe al mundo de lo terrenal, más allá del cual no debe pretender gobernar ni combatir en modo alguno (non debere aliter imperare vel militare), pues esto es competencia exclusiva de los oratores; 2) las cuatro virtudes cardinales de las cuales debe adornarse (simbolizadas por las cuatro gemas) $^{36}$.

Es este, pues, el único acontecimiento relatado por Glaber en el que se presta la debida atencion a cuestiones políticas de calado universal, como las relaciones entre el Papado y el Imperio. Y es que si para Glaber el rey de Francia Roberto el Piadoso no es sino una sombra a la que alude muy de vez en cuando, la figura mítica de un dominus Mundi como Carlomagno apenas le merece una línea.

Otro monje negro cronista, Ademar de Chabannes, un hombre más cultivado que Glaber, trató de escribir una Historia Francorum con pretensiones universales (circa 1028), lo cual se saldría de los parámetros cluniacenses que hemos visto. No obstante, si los dos primeros libros de su crónica mantienen ese discurso historiográfico centrado en el pueblo y la Realeza de

\footnotetext{
${ }^{35}$ Paul E. DutTon, Raoul Glaber's "De Divina Quaternitate": an Unnoticed Reading of Eriugena's Translation of the "Ambigua" of Maximus the Confessor, "Mediaeval Studies", 42 (1980), pp. 431-435.

${ }^{36}$ E. ORTIGUES, Raoul Glaber et l'historiographie clunisienne, "Studi Medievali", 26 (1985), p. 561; vid. en este sentido J. FRANCE, Rodulfus Glaber and French Politics in the Early Eleventh Century, "Francia", 16 (1989).
} 
los Francos se debe exclusivamente a que transcribe íntegramente la Gesta Regum Francorum de Fredegario y los Anales Laurissenses. Así, cuando el relato aborda los hechos ocurridos a partir del año 830 la obra de Ademar se transforma, como le ocurrió a Glaber, en un cronicón localista centrado en las regiones del Limousin, el Périgord y Aquitania, un cronicón que no es sino una Historia pontificum et comitum ${ }^{37}$. Además, como señala Duby, el monje Ademar propone un elogio nobiliario muy significativo: el del duque Guillermo de Aquitania, en quien reconoce una virtud regia a pesar de no estar consagrado: la Sapientia ${ }^{38}$. Y es que este cronista tenía, en palabras de Duby, una clara conciencia del hundimiento de la Realeza ${ }^{39}$ En definitiva, al asomarnos a la ideología política cluniacense no encontramos reflejos de construcciones teóricas complejas del tipo de la Realeza cristocéntrica que el historiador Ernst H. Kantorowicz creyó descubrir en obras del siglo XI como el Anónimo Normando (circa 1100) o el Evangelio de Aquisgrán (circa 973) ${ }^{40}$. Desde el punto de vista cluniacense, en la Realeza cristiana no había elementos teológicos sacralizadores tales como el halo de perpetuidad o la naturaleza geminada. Estas características cristocéntricas las reservaban los monjes a sí mismos, en particular, al abad de Cluny, de quien Juan de Salerno, al escribir la Vita del abad San Odilón, proclamó una doble naturaleza angélica y humana. En efecto, como señala Kantorowicz, en el abad de Cluny, angelicus et humanus, se quería ver un ejemplo en carne y hueso de la vita angelica de los seres celestiales. Siguiendo el esquema cuaternario de Raúl Glaber, el abad de Cluny sería, para Juan de Salerno, el lapis angularis quadrus, la esquina de la piedra angular crística que une dos muros: el de los ángeles y el de los hombres ${ }^{41}$.

\footnotetext{
${ }^{37}$ C. ORCÁstegui; E. SARASA , La Historia en la Edad Media, op. cit., p. 143; vid. John Gillingham, Ademar of Chabannes and the History of Aquitaine in the Reign of Charles the Bald, "Charles the Bald. Court and Kingdom", ed. M. GiBSON, Oxford, 1981, pp. 3-14.

${ }^{38}$ G. DuBy, Les Trois Ordres, op. cit., p. 181.

${ }^{39} \mathrm{G}$. DuBy, Les Trois Ordres, op. cit., p. 195.

${ }^{40}$ Ernst H. Kantorowicz, The King's Two Bodies: A Study in Medieval Political Thought, Princeton, 1957, ed. esp. Los dos cuerpos del Rey. Un estudio de teología política medieval, Madrid, 1985, pp. 53-92.

${ }^{41}$ JUAN DE SALERNO, Vita Sancti Odonis, V: erat enim velut lapis angularis quadrus, angelicus videlicet et humanus (apud E.H. KANTOROWICZ, The King's Two Bodies, op. cit., p. 54, n. 2). Vid. Gerhart B. LADNER, The Symbolism of the Biblical Corner Stone in the Mediaeval West, "Mediaeval Studies", 2 (1940), pp. 43-60.
} 
Por consiguiente, vemos perfilada de forma bastante nítida una historiografía localista, presidida por una indiferencia total hacia la Realeza y la tradición política carolingia, una historiografía que prefiere centrar su relato en un marco geográfico reducido, otorgando el protagonismo a la nobleza feudal y a la iglesia local, a un tiempo que aborda con detalle cuestiones de índole teológica y de disciplina eclesiástica. No cabe duda de la posible influencia que pudo tener la circunstancia de que monasterios como Cluny, Saint-Germain de Auxerre o Saint Martial de Limoges, donde trabajaron y se formaron Raúl Glaber y Ademar de Chabannes, estuvieran situados en regiones donde el rey de Francia era sólo una figura lejana y fantasmagórica, lugares como Aquitania y Borgoña donde la nobleza feudal era el punto de referencia político. Según lo expresa Duby, "la Francia del Mediodía se transformó durante un siglo y medio en una región sin Rey, en una región de príncipes"42. Pero tampoco hay que olvidar que el ignorar y minusvalorar sistemáticamente a la Realeza era parte de la ideología hierocrática propia de la Reforma gregoriana, la cual tuvo en el Ordo cluniacensis su principal punto de apoyo.

\section{EL CONTEXTO IDEOLÓGICO-HISTORIOGRÁFICO \\ DE RAIGAMBRE HISPANA: \\ LA CONTRAPOSICIÓN CON LA MENTALIDAD CRONÍSTICA \\ DE LOS MONJES NEGROS}

Tal y como han puesto de relieve Marcélin Defourneaux y Salvador Martínez, la rápida penetración de la reforma monástica cluniacense en los reinos de León y Castilla no dejó de suscitar enconadas resistencias entre muchos monjes españoles apegados a la tradición hispanomozárabe ${ }^{43}$. Una rica tradición religiosa y cultural que también tenía una vertiente ideológica cuyo eje era la concepción neogótica de una Realeza fuerte y autosuficiente. Si bien

${ }^{42}$ G. DuBY, Les Trois Ordres, op. cit., p. 181.

${ }^{43}$ Marcelin DeFoURNEAUX, Les français en Espagne aux XIe et XIIe siècles, op. cit., p. 27; vid. Salvador MARTínEZ, La rebelión de los burgos. Crisis de Estado y coyuntura social, Madrid, 1992. Para Martínez, las revueltas de los burgos de Sahagún y Compostela a principios del XII habrían de ser enmarcadas en este contexto de enfrentamiento social y cultural entre mozarabismo y monacato cluniacense. Es esta, sin embargo, una compleja cuestión aún no suficientemente estudiada. 
la ideología política del periodo astur-leonés (siglos IX-XI) aún no ha sido estudiada de forma solvente, resulta evidente en ella la fuerte impronta de la herencia visigótica, cuyo legado era una Realeza no tutelada, una Realeza sacralizada por la unción que legisló, en un estilo muy similar al carolingio, en el marco de sucesivos concilios.

Según han puesto de relieve tanto Ernst $\mathrm{H}$. Kantorowicz como Walter Ullmann, la imagen cristocéntrica del Rex ad caelum erectus, recogida por los otónidas y por los reyes normandos de Sicilia, hunde sus orígenes en la España visigoda, en concreto en la Collectio Hispana Isidoriana, una colección de cánones hispanogodos del siglo VII atribuidos a la pluma de San Isidoro de Sevilla ${ }^{44}$. Una Collectio que, junto al Liber Iudicum, constituía la fuente principal de la ideología política del reino de León en los siglos X y XI. De este modo, la maiestas propia de la visión isidoriana de la Realeza se va a contraponer al programa gregoriano del "Rey tutelado" que van a importar con entusiasmo los monjes cluniacenses.

$\mathrm{Al}$ igual que ocurriera en Francia con la oposición a la pujanza política de Cluny por parte de figuras como los obispos Adalberón de Laon y Gerardo de Cambray, en León y Castilla van a surgir dos portavoces de la tradición isidoriana que defenderán la visión neogótica de la Realeza con el mismo celo con el que los obispos francos abogaron un siglo antes por la preservación de la tradición política carolingia. No casualmente, los autores de las dos crónicas hispanas más importantes del periodo inmediatamente anterior al auge del ciclo historiográfico cluniacense, la Crónica de Sampiro y la Historia Silense, presentan una serie de llamativas similitudes: ambos son clérigos aúlicos al servicio del Rey (notario uno, gramático el otro), ambos defienden celosamente la institución regia como epicentro político a un tiempo que guía moral del reino y, finalmente, los dos acabaron siendo recompensados con el obispado de Astorga.

Sampiro, notario real, elevado a maiordomus regis por Alfonso $\mathrm{V}$ de León, fue el último portavoz de la ideología imperial leonesa de raigambre neogoticista a la vez que el último representante de un género cronístico que

${ }^{44}$ E.H. Kantorowicz, The King's Two Bodies, op. cit., pp. 72-73. Walter UllmanN ha incidido también en la importancia de la Collectio pseudo-isidoriana como fuente de argumentos fortalecedores de la Realeza, tales como el topos del Rey ungido ( $A$ History of Political Thought: The Middle Ages, Londres, 1965, ed. esp. Historia del pensamiento político en la Edad Media, Barcelona, 1992, p. 87). 
se iniciaba con la invasión árabe ${ }^{45}$. En su escueto y más bien lacónico relato los protagonistas absolutos son los reyes asturleoneses, sin prestar apenas atención a cualquier otro aspecto, incluido el religioso. Y es que la exaltación de la monarquía imperial leonesa, en la línea de la Crónica de Alfonso III, constituye su principal, sino único, objetivo historiográfico ${ }^{46}$.

Significativamente, el probable autor de la crónica hispana más interesante del ciclo anterior al cluniacense, el grammaticus Alón (que habría compuesto en opinión de Justo Pérez de Urbel la Historia Silense), intercaló íntegramente la Crónica de Sampiro en el seno de su propia obra. Un mismo celo neogoticista por exaltar a la Realeza les unía, viéndose, además, Alón en el trance de defender a esta institución tal y como se la concebía en sus viejos presupuestos teóricos hispanomozárabes contra los "vientos del cambio" cluniacenses. Ahora bien, como veremos, Alón de Astorga, el Silense, no va a dudar en introducir un matiz personal al ideal neogótico: un matiz de índole sapiencial.

Buen dominador de los clásicos, como demuestra la utilización en su crónica de formas poéticas entresacadas de la lectura de Virgilio, Horacio, Ovidio, Lucano y Salustio ${ }^{47}$, resulta ser el máximo exponente de la alta capacidad intelectual de la clerecía aúlica que se formó en la schola palatina del rey Fernando I, un tema sobre el que volveremos después. Alón, conectado a la corte ya hacia el 1090, abandonará el monasterio de Silos para asentarse en el reino de León. En el año 1101 lo encontramos envuelto en un arbitraje de jurisdicciones episcopales en Oviedo, integrado en el séquito del arzobispo de Toledo, el cluniacense francés Bernardo de Sedirac, pero, eso sí, en calidad de grammaticus regis ${ }^{48}$. Y es que Alón, pese a alcanzar el obispado de Astorga en 1122 en calidad de protegido del filocluniacense Diego Gelmírez ${ }^{49}$, nunca simpatizó ni con los francos, ni con los planteamien-

${ }^{45}$ Vid. Justo PÉREZ DE URBEL, Sampiro: notario, cronista y obispo, "Revista de Archivos, Bibliotecas y Museos", 58 (1952), pp. 203-270.

${ }^{46}$ C. ORCÁSTEgUi; E. SARASA, La Historia en la Edad Media, op. cit., p. 197; vid. Justo PÉREZ DE URBEL, Sampiro, su crónica y la monarquía leonesa en el siglo X, Madrid, 1952.

${ }^{47}$ Justo PÉREZ DE URBEL, Introducción de la Historia Silense, Madrid, 1959, p. 84.

${ }^{48}$ J. PÉREZ DE URBEL, Introducción de la Historia Silense, op. cit., p. 85.

${ }^{49}$ J. PÉREZ DE URBEL, Introducción a la Historia Silense, op. cit., p. 85. 
tos hierocráticos cluniacenses. Sus lealtades estaban claras: el Rey y la tradición cultural hispanomozárabe.

Esta línea antifrancesa se comprueba cuando, pese a ser buen conocedor de los anales carolingios y de la Vita Karoli de Eginardo, no duda un ápice en tergiversar los hechos para denigrar al propio Carlomagno, encarnación del ideal de príncipe en los escritos cluniacenses. Así, afirma que el emperador franco abandonó sin más el sitio de Zaragoza porque le compró el oro musulmán (algo que sería acorde con la mos Francorum) y anhelaba regresar a la molicie de sus cómodas termas de Aquisgrán ${ }^{50}$.

No es, pues, de extrañar que sea con una acérrima exaltación de la tradición cultural hispanogoda con la que dé comienzo a su Historia: "Cum olim Yspania omni liberali doctrina ubertim floreret, ac in ea studio literarum fontem Sapientie sitientes passim operam darent". Esta España en la que las Artes Liberales y la fuente de la Sabiduría florecían no es otra que la Hispania visigótica, el reino que alumbró a San Isidoro de Sevilla y Julián de Toledo, cuyas crónicas siguió cumplidamente el Silense.

Este comienzo lleno de enjundia se enriquece aún más cuando concluye que la invasión árabe, descrita como barbarorum fortitudine, hizo que el estudio y la doctrina se desvanecieran y cayeran en el olvido ${ }^{51}$. Esta espectacular apertura de la Historia Silense resulta tremendamente interesante por dos razones: 1) establece la preeminencia y excelencia de la tradición cultural hispano-mozárabe, lo cual no carecía de implicaciones en el contexto en el que escribía, el de un soterrado conflicto cultural entre las formas intelectuales y sociales francoborgoñonas (lo que incluía el rito romano) importadas por Cluny y las pervivencias de la tradición mozárabe; 2) considera tan importante la virtud de la Sabiduría, esto es, la cuestión cultural, que la contrapone favorablemente a la fortitudo (atribuida a los "bárbaros" musulmanes), una virtud mucho más apreciada en el marco de una sociedad volcada en la guerra. Además, decide situar esta cuestión en el centro de su discurso historiográfico, al considerar la decadencia del studium como la principal de las secuelas de la caída de España en manos de los árabes,

${ }^{50}$ Historia Silense, 18, ed. cit.: "Tunc Carolus rex... more Francorum auro corruptus... anelabat etenim Carolus in termis illis citius lavari, quas Grani ad hoc opus delitiose construxerat".

${ }^{51}$ Historia Silense, 1, ed. cit.: "inundata barbarorum fortitudine, studium cum doctrina funditus evanuit". 
dándole así la vuelta a la argumentación de otras crónicas anteriores y posteriores que fijaron también su inicio en la conquista árabe como fuente de innumerables desgracias pero nunca citaron esta consecuencia, como poco insospechada, del desembarco de Tarik. En definitiva, el Silense enmarca el ideal neogoticista de los siglos IX y $\mathrm{X}^{52}$ en unas coordenadas nuevas, las de una renovatio studii gothorum (complemento de la recuperación ovetense del ordo gothorum).

Por consiguiente, estamos ante un pensamiento histórico sapiencialista, que sitúa a la Sapientia como paradigma en torno al cual se organiza su discurso literario. Ello no significa que tergiverse los hechos para construir un manual del buen gobierno. No, a decir verdad, el Silense no quiso escribir un espejo de príncipes y a la hora de retratar a los reyes que le antecedieron en el tiempo, aquellos de los que habla a partir de la lectura de otras crónicas, no fuerza las biografías para construir edificantes modelos de sapiencia regia. De este modo, lo único que podemos entresacar en una línea mínimamente sapiencial de reyes como Ordoño II es su condición de providus atque prudentissimus rex en la guerra, lo cual no implica ninguna atribución de saber $^{53}$. Así, por ejemplo, el que Bermudo I recibiera la instrucción en los literarum studia en su infancia por orden de su padre, no merece ninguna alabanza de Alón, quien incluso señala que ello le capacitó más para los asuntos del Cielo que para gobernar un reino ${ }^{54}$. Y es que, ciertamente, los modelos regios que presenta el Silense son más bien convencionales y bastante ajustados a lo que podría esperarse de los más bien agrestes primeros siglos del reino asturleonés. De Alfonso III el Magno dice que era severus en la administración del reino, providus en el batallar y perspicuus en el culto divino. De Alfonso V ensalza su misericordia con los pobres y las iglesias de Cristo así como su condición de strenuissimus expugnator de la "secta supersticiosa" de los mahometanos, a la que combatió con odio máximo y celo

\footnotetext{
${ }^{52}$ Manuel DíAZ Y DíAZ, De Isidoro al siglo XI, Barcelona, 1978, pp. 233-234; vid. también de este autor La historiografia hispana desde la invasión árabe hasta el año 1000 " "La storiografia altomedievale", XVII Settimane di studio del Centro Italiano di Studi sull'Alto Medioevo, t. 1, Spoleto, 1970, pp. 313-343.

${ }^{53}$ Historia Silense, 42 , ed. cit.: "Erat namque in omni bello providus atque prudentissimus"

${ }^{54}$ Historia Silense, 32 ed. cit.: "Is ab ipsis puerilibus annis iussione patris literarum studia traditus, ubi adolevit, pocius celeste quam terrenum sibi regnum afectavit".
} 
por la ley de Dios $^{55}$. En fin, de Ordoño II construye un acabado retrato en el que destaca su misericordia con los necesitados, más allá de la condición humana, vertiendo una retahíla de epítetos muy elogiosos sobre su forma de administrar el reino tales como iustus, piissimus y honestate preclarus ${ }^{56}$. En conclusión, se puede decir que el Silense no se aparta del retrato del optimus Rex cristiano, enemigo victorioso de los musulmanes y devoto protector de la iglesia y de los pobres, tal y como este se presenta en el ciclo cronístico de la Alta Edad Media hispana y europea.

Esta ortodoxia argumental del Silense hace aún más interesante y llamativa la irrupción del retrato sapiencial de Fernando I. Cuando el lector casi ya ha olvidado el inicio de la crónica y su acendrada proclama sapiencialista, surge de repente ante su mirada, a modo de conclusión de la obra, el relato de la vida de un verdadero Rex sapiens que, siglos después, mostrará una preocupación por la Sabiduría que hacía honor a sus antepasados godos. Se cierra así un círculo en la obra, la ignorancia que los "bárbaros" agarenos habrían traído consigo se subsana al final de la crónica con el brillante reinado de un restaurador del saber.

En efecto, el rey Fernando habría hecho instruir a sus hijos, incluidas sus hijas, en particular la infanta Urraca, en las Artes Liberales, así como en la caza, las armas y la equitación. Esta completa educación otorgada a sus hijos se habría, además complementado con una serie de disposiciones (no explicitadas por el Silense) sobre las Artes Liberales, unas disposiciones que el cronista agrupa, significativamente, junto a una serie de medidas de carácter militar, englobándolas a todas bajo el calificativo de administratio regni $i^{57}$.

${ }^{55}$ Historia Silense, 73 , ed. cit.: "in ecclesias et pauperes Christi misericordie visceribus satis afluentem, atque barbarorum et eorundem civitatum strenuissimum expugnatorem. Verum legem Dei zelando, cum barbaricam superstitiosam sectam maximo odio propulsaret".

${ }^{56}$ Historia Silense, 42, ed. cit.: "in civibus iustus et misericordissimus, in miserorum et pauperum necessitudinibus ultra modum humanum misericordie visceribus affluens et piissimus, atque in universa gubernandi regni honestate preclarus".

${ }^{57}$ Historia Silense, 81 , ed. cit.: "Rex vero Fernandus filios suos et filias ita censuit instruere, ut primo liberalibus disciplinis, quibus et ipse studium dederat, erudirentur; dein, ubi etas patiebatur, more Ispanorum equos cursare, armis et venationibus filios exercere fecit, sed et filias, ne per otium torperent, ad omnem muliebrem honestatem erudiri iusit. Igitur, administratio regni Fernandi regis, post ubi liberis moribus militibusque aucta..." Ha llamado mi atención sobre este pasaje Adeline RUCQUOI, quien considera cręible esta información en el marco de una historia de la educación en la España medieval [Education et societé dans la Péninsule Ibérique médiévale, "Histoire de l'Éducation", 69 (1996), p. 9]. 
Ahora bien, lo verdaderamente importante es que Fernando, serenissimus Rex, no habría llevado a cabo estas cosas arbitrariamente sino siguiendo las admoniciones de la Biblia. El Silense se las ingenia para describir con mano maestra una escena de mesianismo regio que no tiene desperdicio: durante la ceremonia de celebración de la Navidad, un coro de clérigos entona en presencia del Rey castellano un canto de maitines según el rito mozárabe (more Toletano, una alusión nada inocente) en el cual se invoca el precepto salomónico tantas veces repetido en el Medievo sobre la necesidad de que los reyes sean sabios: Erudimini omnes qui iudicatis terram. Por supuesto, el cronista se apresura a declarar que Fernando lo ha cumplido a plena satisfacción, ya que ha gobernado católicamente el reino en tanto que Rex eruditus ${ }^{58}$. Así pues, resulta indudable que Alón de Astorga, el Silense, estableció una justificación ideológica de raíz bíblica para la actuación del mónarca, una justificación que nos enfrenta a un modelo conscientemente evocado de Realeza sapiencial.

En consecuencia, en los años en los que se inicia el ciclo historiográfico cluniacense en León y Castilla nos encontramos con una tradición historiográfica de raigambre hispano- mozárabe que ha alcanzado su madurez en la brillante figura del Silense, Alón de Astorga, quien había dotado a la Realeza castellanoleonesa de un nuevo propósito en su empresa de restauración del ordo gothorum a la vez que una áureola legitimadora que podría haber sido sumamente eficaz como bien se demostraría un siglo después. Decimos "podría" porque la Realeza sapiencial del Silense no va a encôntrar demasiado eco en los cronistas cluniacenses. Sencillamente, no encajaba en el modelo de Realeza feudalizante e hierocrático que iban a promover en los reinos hispanos.

${ }^{58}$ Historia Silense, 105 , ed. cit.: "Ceterum in ipsa celebri nativitatis Dominice nocte, cum clerici festivo more natalicium matitutinum canerent, adfuit inter eos dompnus rex, atque virtute que poterat letus concinere cepit ultimum sonoum matutinorum:" Advenit nobis, "quem nunc temporis more Toletano canebant, succentoribus autem respondentibus": Erudimini omnes qui iudicatis terram, "quod Fernando serenissimo regi non incongrue tunc conveniebant, qui dum vivere sibi licuit, et regnum catholice gubernavit et seipsum, presso impudicicie freno, funditus eruditum reddidit". 


\section{LA "HISTORIA RODERICI" ¿PRIMERA CRÓNICA DEL CICLO CLUNIACENSE?}

Puntualizando desde un principio que casi todo lo que concierne a la autoría y fecha de redacción de esta crónica permanece aún al brumoso terreno de lo hipotético, queremos aventurarnos a utilizar una de las teorías más factibles sobre las circunstancias de su redacción para así poder engarzar esta interesante obra en nuestra propuesta de ciclo historiográfico cluniacense.

La teoría en cuestión es la de José Luis Moralejo, quien apunta como autor de la Historia Roderici al francés Jerónimo de Perigord, monje cluniacense y obispo de Valencia (1098-1102) durante el efímero dominio cidiano de la ciudad. Jerónimo, canónigo de Toledo en su calidad de miembro del séquito del poderoso Bernardo de Sedirac, habría marchado a Valencia en el año 1098 para asumir la mitra de la ciudad ${ }^{59}$. Así pues, Jerónimo de Perigord era, sin duda, un cualificado portavoz de la primera generación de cluniacenses franceses venida a España. De él dice el Cantar del Mio Cid que bien entendido es de letras e mucho acordado, un obispo guerrero que celebraba misas antes de la batalla y "de pie e de cavallo mucho era areziado, sospirando ques viese con moros en campo" ${ }^{\text {. }}$. En cualquier caso, si bien es cierto que otros autores prefieren otorgar otra cronología a la Historia Roderici, apuntando a la década $1140-1150^{61}$ como fecha probable de redacción de la obra, ninguno presenta un candidato a la autoría. En lo que si están de acuerdo es en señalar el origen no castellano del autor y su probable condición de clérigo francés o leonés, amén de alguien que pudo consultar el archivo cidiano en Salamanca (condiciones todas que reúne Jerónimo de Perigord, obispo de esta ciudad al final de su vida) ${ }^{62}$.

${ }^{59}$ J.L. MORALEjo, Literatura Hispano-latina (siglos V-XVI), "Historia de las Literaturas Hispánicas no castellanas", ed. J.M. DíEZ BORQUE, Madrid, 1980, p. 65.

${ }^{60}$ Poema de Mio Cid, vv. 1290-1291, ed. C. SMITH, Madrid, 1996, p. 192.

${ }^{61}$ Vid. Antonio UBIETO, La "Historia Roderici" y su fecha de redacción, "Saitabi”, 11 (1961), pp. 241-246 y Colin SMITH, The Dating and Relationship of the "Historia Roderici" and the "Carmen Campi Doctoris", "Olifant", 9 (1982), pp. 99-112.

${ }^{62}$ Vid. Emma FALQUE, ed., Historia Roderici, Introducción, "Chronica Hispana Saeculi XII", “Corpus Christianorum: Continuatio Medievalis", t. 71, Turnholt, 1990, pp. 11-14; Colin SMITH, The Making of the Poema de Mio Cid, Cambridge, 1983, ed. esp. La creación del Poema de Mio Cid, Barcelona, 1985, pp. 75-78. En esta dirección también van las elucubraciones de Jacques HORRENT (Chroniques latines primitives et chansons de geste espagnoles, "Etudes de Civilisation Médiévale (IXe-XIIle siècles). Mélanges offerts à Edmond-René Labande”, Poitiers, 1974, pp. 
Emma Falque apunta en esta dirección que las similitudes estilísticas y de fondo entre el exordium de la Historia Compostelana, compuesto por el francés Gerardo el presbítero, y la introducción de la Historia Roderici pueden denotar el hecho de que el autor de esta última tuviera acceso a la primera $^{63}$. Ello, claro está, indicaría una fecha postquem de redacción a partir de 1140 , aunque también pudiera no ser otra cosa que el síntoma de una afinidad ideológica y cultural entre ambas obras, una afinidad muy lógica como veremos.

De cualquier forma, no nos atañe aquí el dilucidar la fecha de redacción o la autoría de la Historia Roderici. Lo que realmente nos interesa es un hecho básico: independientemente de si fue realmente compuesta por Jerónimo de Perigord hacia el 1102 o lo fue por un clérigo francés hacia el 1140, la Gesta Roderici Campidocti presenta un discurso muy parejo al del ciclo historiográfico cluniacense (en el que insertamos a la Compostelana, de la cual ya se han citado las similitudes con la crónica de Rodrigo).

La característica más llamativa de la Historia Roderici es su condición de "panegírico monográfico"64 de la figura de Rodrigo Díaz de Vivar, el Cid, un noble castellano desterrado por Alfonso VI de quien se construye una imagen heroica que contrasta con el oscuro papel que se otorga al propio rey en la narración. De hecho, transmitirá una velada imagen de Rex tyrannus de Alfonso VI de la que se haría eco décadas después el Cantar de Mio Cid ${ }^{65}$, una imagen negativa que contrasta tremendamente con el perfil favorable que, de forma unánime, nos presentan del conquistador de Toledo todos los cronistas del Medievo hispano.

La imagen heroica del Cid que nos presenta la Historia Roderici está apoyada en una serie de epítetos como vir bellator fortissimus o campidoctus in aula regis ("campeador" o lo que es lo mismo: "sabio en el campo de batalla"), así como en el relato de una serie de hazañas guerreras ${ }^{66}$. Pero la gloria militar del Cid habría atraído no sólo la envidia de los maiores curiae

407-415). A tenor de los contenidos ideológicos de la obra, consideramos improbable una autoría leonesa, inclinándonos, de no ser factible la hipótesis de Moralejo, por un autor francés en cualquier caso.

${ }^{63}$ E. FAlQUe, ed., Historia Roderici, Introducción, op. cit., p. 13.

${ }^{64}$ E. FALQUE, ed., Historia Roderici, Introducción, op. cit., p. 14.

${ }^{65}$ Vid. Colin SMITH, The Making of the Poema de Mio Cid, op. cit.

${ }^{66}$ Historia Roderici, V, ed. cit., p. 48. 
sino también la enemistad del Rey, quien acogió las nuevas de una victoria del Cid dure et moleste. Ante las insinuaciones de los envidiosos de la corte, la ira regia habría estallado contra don Rodrigo, desterrándole "injustamente" del reino. Este sucinto relato, contenido en el capítulo XI, es todo él un sutil ataque contra el rey de León y Castilla. Indudablemente, conceptos como iniuste, iratus o invidia suggestione suponen aquí una velada acusación de tiranía contra Alfonso $\mathrm{VI}^{67}$. Este retrato desfavorable se completa en el capítulo XXXIV cuando el rey, atendiendo de nuevo las calumnias de los "envidiosos", da pábulo a estas y sobrecogido de una ira maxima, ordena que se le arrebaten al Cid todas sus posesiones y honores, así como que se ponga bajo custodia a su mujer y a sus hijas. Aquí el cronista no se recata en calificar los actos del rey como "crueles": crudeliter retrudi ${ }^{68}$.

Ante estas acusaciones, el Cid, a quien se brindan ahora nuevos epítetos laudatorios como militem probissimum o fidelissimus vassallus despliega un comportamiento lleno de mesura y fidelidad que contrasta vivamente con la inquina regia hacia su persona. Este Cid muestra un perfil perfectamente homologable con el ideal francoborgoñón del gran señor feudal, manteniendo relaciones de amicitia con reyes como Pedro de Aragón, fundando iglesias, arengando a su hueste... Todo ello, preciso es recordarlo, también perfectamente ajeno a la tradición política propiamente hispánica, en la cual era la Realeza el epicentro de los acontecimientos.

Además, el modelo nobiliario que encarna el Cid se ajusta al del bellator feudal. Así, en su arenga a la hueste previa a la toma de Valencia el cronista pone en su boca giros como fortes et potentes in bello ${ }^{69}$, mientras que, orando en público en la ciudad una vez tomada, don Rodrigo alude a la fortitudine gladii como un don divino ${ }^{70}$. Creemos que no es aventurado ver en

${ }^{67}$ Historia Roderici, XI, ed. cit., p. 51: "Ut autem rex Aldefonsus et maiores sue curie hoc factum Roderici audierunt, dure et moleste acceperunt et huiusmodi causam sibi obicientes sibique curiales invidentes regi unanimiter dixerunt... Huiusmodi prava et invidia suggestione rex iniuste commotus et iratus eiecit eum de regno suo".

${ }^{68}$ Historia Roderici, XXXIV, ed. cit., p. 63: "Rex autem, huiusmodi accusatione falsa audita, motus et accensus ira maxima statim iussit ei auferre castella, villas et omnem honorem, quem de illo tenebat. Necnon mandavit intrare suam propriam hereditatem et, quod deterius est, suam uxorem et libero in custodia illaqueatos crudeliter retrudi..."

${ }^{69}$ Historia Roderici, LXVI, ed. cit., p. 91: "Audite me, socii mei dilectissimi et dulcissimi, estote fortes in bello et potentes..."

${ }^{70}$ Historia Roderici, LXVIII, ed. cit., p. 93. 
esta imagen cidiana un modelo heroico-feudal de inspiración cluniacense y proyección hierocrática, en el cual el miles concilia su condición de instrumento de Dios con un larvado enfrentamiento con un rey inicuo, del cual es fiel vasallo, sí, pero nunca sumiso servidor. Ello estaría acorde con el espíritu de santificación de la caballería al que el abad Odón de Cluny había dado carta de naturaleza hacia el 944 con su rupturista hagiografía de un miles santo: San Gerardo (la figura del guerrero era hasta entonces muy mal vista desde una perspectiva moral cristiana).

En fin, quizá debido a que la historia del Mio Cid nos es tan familiar, no se ha reparado suficientemente en lo excepcional del planteamiento político subyacente en la glorificación de este personaje desterrado y maltratado por el Rey. Un personaje cuya reivindicación suponía, de algún modo, una toma de partido por la nobleza castellana frente a la Realeza, por un modelo feudalizante castellano frente a la tradición imperial leonesa. Esta dicotomía Realeza leonesa-nobleza castellana ya ha sido analizada de forma muy solvente por Georges Martin el marco de otro ciclo historiográfico: la leyenda de los jueces de Castilla (uno de los cuales, Laín Calvo, sería el antepasado del propio Rodrigo Díaz de Vivar) ${ }^{71}$. Por tanto, no resulta una interpretación aventurada el suponer una intencionalidad política de este tenor en la Historia Roderici. Insistimos, pues, en que es esta perspectiva ideológica, independiente de su aún no aclarada autoría, la que nos anima a incluir, a título de hipótesis, esta crónica en el ciclo cluniacense.

Como comprobaremos al abordar la Chronica Naierense, el tema cidiano inaugurado por la Historia Roderici va a dar lugar todo un ciclo épico pronobiliario de factura monástica que si bien alcanzará su culmen con el Poema del Mio Cid, compuesto por laicos, fue antes desarrollado por monjes, pues monjes fueron el autor del Carmen Campidoctoris (poema compuesto hacia 1093 por un monje de Ripoll) ${ }^{72}$ y el del Carmen de morte Sanctii Regis

${ }^{71}$ Vid. Georges MARTIN, Les juges de Castille; Mentalités et discours historique dans l'Espagne médiévale, París, 1992.

${ }^{72}$ Juan GIL, ed., Carmen Campidoctoris, Introducción, "Chronica Hispana Saeculi XII", op. cit., p. 101. Por cierto que este poema expone también brevemente el tema de la ira regia de Alfonso VI, con las insinuaciones de los envidiosos del aula regia, añadiendo que este temía perder el trono a manos del Cid: "Donec ceperunt ei invidere / Compares aule / Dicentes regi: Domine, quid facis? / Contra te ipsum malum operaris, / Cum Rodericum sublimari sinis. / Displicet nobis. / Sit tibi notum: te nunquam amabit, / Quod tui fratris curialis fuit; / Semper contra te mala cogitabit / Et preparabit. / Quibus auditis susurrronum dictis, / Rex Eldefonsus, tactus zelo cordis, Pedere timens solium honoris, / Causa timoris / Omnem amorem in iram 
(poema compuesto por un monje de Oña) ${ }^{73}$. Muy importante es el Carmen Campidoctoris, que procede a una temprana "heroización" de la figura del Cid apoyada en su asimilación con los héroes homéricos de la Guerra de Troya ${ }^{74}$. Esta heroización filonobiliaria sentó un precedente literario del que se van a hacer eco otras crónicas del ciclo cluniacense como la Historia Naierense, la Historia Compostelana y la Chronica Adefonsi Imperatoris. En esta dirección, Antonio Antelo ha apuntado la relación existente entre fenómenos como el auge del ordo cluniacense y la difusión del género épico en los reinos hispánicos ${ }^{75}$.

No ha llamado demasiado la atención, en el nivel de análisis político, el hecho, cuando menos curioso, de que el ciclo épico cidiano sea el primero de una larga serie de cantares de gesta castellanos (romances o latinos) en los cuales el Rey no es el protagonista y a veces es, incluso, el antagonista del héroe (como ocurre en el Poema de Fernán González) ${ }^{76}$. Sólo desádè el campo de la filología apunta, en solitario, Colin Smith que la Historia Roderici es una obra excepcional por ser la primera en España en narrár la vida de una persona no perteneciente a la Realeza ${ }^{77}$.

Algo que contrasta con ciclos épicos de otros países donde se dieron cantares de ambas tendencias, una filonobiliaria de influencia eclesiástica y otra laica promonárquica. Así, por ejemplo, en Francia contamos con el eiclo épico de Carlomagno (cuya obras cumbre son la Chanson de Roland, Le Pélerinage de Charlemagne y la Chanson de Guillaume) como expresión de la mitificación del emperador de la barba florida y, por extensión, de la Realeza francesa. También es cierto que el género de las chansons de geste debía mucho conceptual y estilísticamente a las fórmulas litúrgicas y a los textos hagiográficos, siendo algunos cantares instrumento de una propaganda dirigida desde ambientes eclesiásticos pero, en general, los estudiosos del

convertit" (Carmen Campidoctoris, vv. 47-61, ed. cit., p. 106).

${ }^{73}$ Colin SMITH, ed., Poema de Mio Cid, op. cit., Introducción, p. 97.

${ }^{74}$ Carmen Campidoctoris, vv. 125-128, ed. cit., p. 108: "Talibus armis ornatus et equo, / Paris vel Hector meliores illo / nunquam fuerunt in Troiano bello / sunt neque modo".

${ }^{75}$ A.ANTELO, Santiago y Cluny: poder eclesiástico, letras latinas y epopeya, "Compostellanum", 39 (1994), pp. 367-369.

${ }^{76}$ Es algo que apunta tímidamente Salvador MARTíNEZ en su artículo Tres leyendas heroicas de la Najerense, "Anuario de Letras", 9 (1971), p. 173, n. 103.

${ }^{77}$ Colin SMITH, ed., Poema de Mio Cid, op. cit., Introducción, p. 96. 
tema coinciden en señalar la tradición cultural laica en la que bebieron los primeros poema épicos franceses ${ }^{78}$.

Por tanto, nos encontramos ante una cierta peculiaridad literaria castellana, a la que habría también que asociar la particular idiosincrasia social del "principado feudal" de que hablara el admirado Salvador de Moxón ${ }^{79}$. Un fenómeno literario que habría que ligar, en sus orígenes, a la misma fuente de inspiración hierocrático-feudal que detectabamos en el ciclo cronístico que estamos analizando: Cluny, quien habría importado los ideales caballerescos franceses en clave gregoriana, modificando la ética nobiliaria propiamente hispánica.

\section{EL DISCURSO HISTÓRICO FILOCLUNIACENSE DE GERARDo DE BEAUVAIS EN LA "HISTORIA COMPOSTELANA"}

A diferencia de la Historia Roderici, esta crónica no presenta dudas sobre su autoría. Y entre sus autores no hay ningún monje cluniacense. Además, ni siquiera es una crónica del género monástico, sino que fue compuesta en un capítulo catedralicio por encargo de un obispo. Como su propio título indica (De Rebus Gestis Domini Didaci Gelmirez), la obra está concebida para glorificar la figura del arzobispo de Compostela, Diego Gelmírez. Sin embargo, tenemos razones de peso para incluirla en el ciclo historiográfico que estamos abordando ${ }^{80}$.

En primer lugar, consideramos muy importante el hecho de que dos de los autores de la Historia Compostelana fueran franceses: el arcediano Hugo de Portugal (llamado así debido a que posteriormente fue elevado a la mitra de Oporto) y el magister Gerardo de Beauvais (Giraldus presbyter) ${ }^{81}$. Si bien es cierto que no eran monjes y que, al menos, uno de ellos se formó

${ }^{78}$ Franco CARDINI, El guerrero y el caballero, "El hombre medieval", ed. J. LE GoFf, Madrid, 1990, p. 91.

${ }^{79}$ Vid. Salvador de Moxó, Castilla, ¿principado feudal?, "Homenaje a Menéndez Pidal”, 3 [= "Revista de la Universidad de Madrid", 73 (1970)].

${ }^{80}$ Esta vinculación de la escuela historiográfica compostelana con Cluny ha sido resaltada, si bien tímidamente, por Antonio ANTELo (Santiago y Cluny, art. cit., pp. 357-365).

${ }^{81}$ Vid. Emma FAlQUE, Los autores de la "Historia Compostelana", "Habis", 15 (1984), pp. 157-171 y Luis SAla, Los autores de la "Historia Compostelana", "Hispania", 3 (1943), pp. 16-69. 
en una schola catedralicia francesa (bebiendo, por tanto, en las primeras aguas del renacimento del siglo XII), no cabe duda de que su nacionalidad explica alguno de los contenidos ideológicos de la obra. En cuanto a su relación con los monjes negros, hay que consignar que Hugo de Portugal, siendo ya obispo de Oporto, mantuvo un estrecho contacto con el abad Poncio de Cluny como relata la propia Historia ${ }^{82}$. Y no deja de ser un dato interesante, en este sentido, el que Gerardo acabara siendo abad, tan letrado como religioso, y asistiera, en compañía de Pedro el Venerable a la consagración del altar de San Lorenzo de la abadía de Morigny por parte del papa Inocencio II en el año $1131^{83}$.

En segundo lugar, como venimos argumentando a lo largo de este trabajo, opinamos que es en la similitud básica del discurso histórico-ideológico de la Historia Compostelana con el de otras crónicas cluniacenses del siglo XII, en donde reside el punto de apoyo para incluir esta obra dentro del ciclo historiográfico que estamos analizando (coincidencia ideológica que justificaremos a lo largo de este capítulo).

En tercer y último lugar, la estrecha alianza política establecida entre el ambicioso arzobispo compostelano, tutor de Alfonso Raimundez y aspirante a la primacía de su sede en España ${ }^{84}$, y la poderosa Orden de Cluny, invita a presuponer una cierta afinidad ideológica entre los postulados cluniacenses y el discurso historiográfico de los canónigos al servicio de Diego Gelmírez. Numerosos ejemplos de esta afinidad los encontramos en la propia Historia Compostelana. Xavier Garrigós escribe a este respecto que hay motivos más que suficientes para concluir que las relaciones entre el arzobispo y Cluny fueron muy cordiales $y$ frecuentes ${ }^{85}$. No es aventurado pensar, señala Garrigós, que los emisarios del arzobispo ante el Papa utilizaran Cluny como lugar de consulta previa, algo que él mismo hizo en $1104^{86}$. Finalmente, si Gelmírez acabó obteniendo la dignidad arzobispal para su sede fue, principal-

\footnotetext{
${ }^{82}$ L. SAlA, Los autores de la "Historia Compostelana", art. cit., p. 47.

${ }^{83}$ E. FALQUE, ed., Historia Compostelana, Introducción, Madrid, 1994, pp. 13-14. 1949.

${ }^{84}$ Vid. A.G. BIGGS, Diego Gelmírez. First Archbishop of Compostela, Washington D.C.,

${ }^{85}$ X. GARRIGós, La actuación del arzobispo Gelmírez a través de los documentos de la Historia Compostelana, "Hispania", 3 (1943), p. 379.

${ }^{86}$ X. GARRIGÓs, La actuación del arzobispo Gelmírez, art. cit., loc. cit.
} 
mente, debido a las presiones ejercidas por Cluny sobre el papa Calixto II, él mismo un cluniacense. Y es que, según señala la propia Historia Compostelana, la amicitia entre Cluny y Gelmírez hizo que el abad de abades Ponce se inmiscuyera en este negotium ${ }^{87}$. La amicitia entre los monjes negros y Diego Gelmírez queda reflejada plásticamente en una serie de cartas transcritas en la Historia Compostelana. En una de ellas, el abad Poncio habla de la fidelis devotio y sincera dilectio por Cluny que los monjes negros que habían viajado a Compostela habían hallado en el arzobispo, quien siempre tenía en su boca y en su corazón a la Orden monástica ${ }^{88}$. Del mismo tenor es otra carta del abad Poncio, en la que se alude a la relación "especial" (specialiter) de pio afecto y eximia devoción que dispensa el arzobispo compostelano a la domus beati Petri (esto es, Cluny), proclamándose a su vez el abad praecordialis et singularis amicus de Gelmírez y exhortándole a sustentar a la Orden ${ }^{89}$.

Pedro el Venerable, sucesor de Poncio al frente de los monjes negros, escribirá diez años después (1131) otra carta a Diego Gelmírez en la que se comprueba que las relaciones seguían siendo excelentes: "damos gracias por tanta delicadeza, por tan ferviente y perseverante amor con que a nosotros y a nuestras cosas ayudáis y sustentáis.... no dejéis de usar de la benignidad acostumbrada respecto a nuestras cosas (sic) que están cerca de vosotros" ${ }^{90}$.

Resulta, pues, indudable que la amicitia entre Cluny y Gelmírez fue una realidad política firmemente asentada. Pero, ¿tuvo esto implicaciones en el nivel de las mentalidades políticas reflejadas en la Historia Compostelana? Creemos que sí. En particular en lo que toca a los capítulos de la crónica que compuso Gerardo de Beauvais. De entre estos capítulos merece especial mención el capítulo XIV del libro segundo, que es en sí mismo un panegírico de Cluny digno del más entusiasta monje negro.

Este capítulo da cuenta de las desavenencias entre el abad Poncio de Cluny y el arzobispo Guido de Vienne (hermano del conde de Galicia, el

\footnotetext{
${ }^{87}$ X. GARRIGÓs, La actuación del arzobispo Gelmírez, art. cit., p. 379 (Historia Compostelana, II, c. 11).

${ }^{88}$ Historia Compostelana, II, c. 34, ed. FloreZ, España Sagrada, XX, Madrid, 1765 (reed. 1965), p. 318: "vestra fidelis devotio et sincera dilectio quam erga nos habetis, multum nos vobis efficit debitores: referunt namque nobis fratres nostri a vobis venientes, quoniam nos semper in corde et in ore vestro sumus" (la carta está fechada en el año 1121).

${ }^{89}$ Historia Compostelana, II, c. XLIV, ed. lat. cit., pp. 337-338.

${ }^{90}$ Historia Compostelana, III, c. XXVI, ed. E. FALQUE, p. 538.
} 
borgoñón Raimundo), quien era también monje cluniacense. Como fruto de estas desavenencias, cuando Guido de Vienne es elevado en 1119 al solio pontificio con el nombre de Calixto II, el abad de abades se muestra reticente ante la elección y espera un tiempo antes de aprobarla con reluctancia. Un año después, Calixto II tendrá su particular Canossa, una escena de humillación de la dignidad papal que Gerardo de Beauvais se complace en relatar. En efecto, el papa viajó a la abadía de Cluny en la Navidad del año 1120 para postrarse derramando lágrimas (postravit se humi con lacrymis) delante del abad Poncio y de todo el capítulo cluniacese, una gloriosa caterva monachorum que se erigía en juez de un Vicario de Pedro que actuaba como un novicio atrapado en una falta ${ }^{91}$. A continuación, no podía ser de otra forma, el abad y sus monjes se postran también y ruegan al Papa que se levante.

Ya todos erguidos, Calixto II inicia un largo discurso en el que proclama sin ambages que la excellentia charitatis de los monjes negros ha subyugado al mundo, razón por la cual desea volver a ser confratrem et conmilitonem de la Orden y se muestra arrepentido de haberles faltado por amaros menos $^{92}$. Esta escena cuasipenitencial de humillación pontificia termina con la única conclusión posible. El breve pulso que Calixto II había mantenido con Cluny había demostrado quien ejercía realmente el liderazgo espiritual de Occidente cristiano y al pontífice no le queda otro remedio que declarar que los asuntos más importantes de la Iglesia Romana serán resueltos con vuestro consejo ${ }^{93}$, supeditándose la Sede Romana al arbitrio et consilio de la poderosa Orden. En esto consistió, pues, el nuevo vínculo de amor entre la congregación cluniacense y el Pontificado, un vínculo que enseguida empezaría a operar en beneficio de Gelmírez, quien obtendría inmediatamente de Calixto II la anhelada dignidad arzobispal, por mediación de su amicus Ponce, amo y señor de la Iglesia en esos instantes.

${ }^{91}$ Historia Compostelana, II, c. XIV, ed. lat. cit., p. 285: “Die vero Epiphanie Domini Calixtus Papa venit in Capitulum praesente Abbate cum tanta tamque gloriosa caterva Monachorum. Tunc magna caritatis gratia compunctus prostravit se humi cum lacrymis coram Abbate et Cluniacensi Conventu" (ed. E. FALQUE, p. 326).

${ }^{92}$ Historia Compostelana, loc. cit.: “... desidero me confratrem et conmilitonem vestrum haberi: video enim quia charitatis vestrae excellentia totum mundum subjugavit. Si quid minus diligendo vos usquemodo circa partem vestram deliqui, poenitet modo".

${ }^{93}$ Historia Compostelana, loc. cit.: "maiora negotia Romanae Ecclesiae quae his in partibus definienda fuerint, consilio vestro praecipue definiantur, persona mea arbitrio et consilio vestro suppeditetur" (ed. E. FALQUE, pp. 326-327). 
Este capítulo tiene un colofón acorde con los hechos descritos, un colofón a modo de panegírico final que creemos muy indicativo del ánimo procluniacense del cronista: "A decir verdad, el monasterio de Cluny aventaja a todas las iglesias de Francia y destaca por encima de ellas en santidad y caridad. Por ello interesaba al papa Calixto que el monasterio de Cluny fuera muy íntimo suyo, su refugio y apoyo" ${ }^{94}$. Se había reparado en este pasaje de la crónica por parte de Emma Falque y otros autores con el fin de subrayar la nacionalidad de Gerardo de Beauvais ${ }^{95}$, pero nosotros aquí vemos algo más: una devotio singularizada por el Monasterium, acorde con la amicitia que los monjes negros habían mostrado por el señor de Gerardo, el arzobispo Gelmírez. Esto lo corrobora el hecho de que un clérigo hispano como Munio Adefonsiades, el tesorero de la iglesia de Santiago que inició la Historia Compostelana, dedique parecidos elogios a Cluny, de la que habla con encomio llamándola cabeza de toda la religión monástica, una santísima congregación que, en su opinión, existe por voluntad divina ${ }^{96}$. No sería, por tanto, solamente debido a la nacionalidad el enfoque de Gerardo. Se trataría, más bien, de una línea ideológica.

Una línea ideológica que también estaría presente en el Liber Beati Iacobi (integrado en el célebre Codex Calixtinus), obra de un clérigo francés asentado en Compostela, el presbítero Aymerico Picaud (el Pictavense). En el Liber Beati Iacobi, compuesto hacia 1134 y falsamente ligado por el propio autor a la figura del papa cluniacense Calixto II, encontramos un espíritu muy similar al de la Historia Compostelana: exaltación de Cluny, promoción de Compostela en tanto que lugar de peregrinación, compromiso con los intereses de Diego Gelmírez ${ }^{97}$... Es significativa, además, la inclusión de un anuncio profético: cuando se caiga la llave de la estatua de Hércules en Cádiz aparecerá un rey galo que recuperará España de los moros: como ha dicho el profesor Diego Catalán, la Gesta Dei per Francos se proyectaba así al sur de

${ }^{94}$ Historia Compostelana, loc. cit., ed. E. FALQUe, p. 327.

${ }^{95}$ E. FALQUE, Los autores de la Historia Compostelana, art. cit., p. 162.

${ }^{96}$ Historia Compostelana, I, c. XVI, ed. lat. cit., p. 45: "Cluniacum, videlicet ad caput totius Monasticae Religionis... illius Sanctissimae Congregationis quam ibi divinitus profecto esse credimus" (ed. E. FALQUE, p. 101); L. SALA, Los autores de la "Historia Compostelana", art. cit., p. 51

${ }^{97}$ Vid. Manuel DíAz Y DíAZ, El "Liber Sancti Iacobi". Situación de los problemas, “Compostellanum", 32 (1987), pp. 359-442. De hecho, Bédier y otros muchos autores de la primera mitad de nuestro siglo llegaron a atribuir su autoría a un monje cluniacense. 
los Pirineos ${ }^{98}$. Este tema milenarista encaja a la perfección con el programa filofrancés de Cluny y con la exaltación carolingia que más adelante se descubre en la Chronica Adefonsi Imperatoris. Y es que parece que en la corte de Alfonso VII el Liber Beati Iacobi tuvo una gran acogida. Una acogida no mayor que la que se dispensó allende los Pirineos a la Guía del peregrino o a la exitosa Historia Rotholandi del Pseudo-Turpin, una chanson de geste que constituye el cuarto libro del Codex de Calixto II.

Realmente, la inclusión en el marco del Codex Calixtinus de este cantar de gesta (una narración fantástica de los hechos de armas de Carlomagno atribuida al arzobispo Turpin de Reims) constituye el mejor indicio posible de la estrecha vinculación existente entre el género épico hispánico y la historiografía cluniacense. Hay que recordar que el Codex es ante todo un compendio de homilías, ceremoniales jacobeos y relatos hagiográficos. Así pues, la inclusión en su seno de la Historia del Pseudo-Turpín sólo se explica a partir de dos motivos: 1) el hecho probado de que la composición original de la Historia Rotholandi tuvo lugar en ambientes cluniacenses de Borgoña (puede que, incluso, en el círculo del propio Calixto II) ${ }^{99}$; 2) los buenos ojos con los que la mentalidad cluniacense contemplaba un género literario que estaba contribuyendo a promocionar.

Puesta en claro la estrecha vinculación ideológica de la Historia Compostelana con el espíritu cluniacense, vamos a abordar el pensamiento estrictamente político de la crónica. Que la Historia Compostelana es algo más que un relato de los acontecimientos nos lo indica su propio exordium inicial: "los antiguos padres, preocupados por la educación y la formación de la posteridad... juzgaron que estas cosas en modo alguno debían ser entregadas al olvido sino más bien tenían que recordarse de manera viva y duradera, para que los que vinieran detrás, al leerlas con bastante frecuencia anotaran en las mismas historias las costumbres y las alabanzas de los sabios y de las personas virtuosas, y estimulados hacia la virtud, por el recuerdo de las hazañas desearan imitar a los ejemplares y diligentes varones en virtud y diligencia y seguir sus pasos, y evitaran por el contrario los vicios y las malas

${ }^{98} V i d$. Diego Catalán, El "Iacobus": la "Gesta Dei per Francos" en Compostela, conferencia pronunciada en el curso de la Mesa Redonda "Identidad y representación de la frontera en la España medieval (ss. XI-XIV)", Madrid (Casa de Velázquez-UAM), 14-15 diciembre, 1998, en prensa.

${ }^{99}$ Manuel DíAz y DíAZ, El "Liber Sancti Iacobi", art. cit., pp. 391-392. 
costumbres de los necios" ${ }^{100}$. Conceptos como instructio, eruditio e imitatio aplicados a la memoria histórica indican bien a las claras que esta crónica no pretende sin más narrar las res gestae: hay una intencionalidad didáctica, especular en lo que toca a la enseñanza política. No olvidemos esto a la hora de analizar los perfiles regios que nos presentan, de forma nada inocente, los redactores de la Historia Compostelana.

En esta dirección, llama la atención en primer lugar un topos que se repite con insistencia, el del Rex tyrannus. Este arquetipo político, caro al pensamiento hierocrático, va a ser aplicado indistintamente por la Historia Compostelana en dos niveles diferentes: la Querella de las Investiduras y el enfrentamiento entre Urraca y Alfonso el Batallador por el control de los reinos de León y Castilla. En ambos conflictos, el cronista toma abiertamente partido por el bando clerical (bien el Papado, bien Urraca) y aplica la imagen tiránica a sus oponentes, paladines ambos de una Realeza fuerte.

De esta forma, al emperador alemán Enrique V, excomulgado por Calixto II, se le alude siempre como tyrannus Teutonicorum y únicamente en una ocasión se le llama por su nombre e intitulación. El cronista le acusa de pretender reunir en sus manos las dos espadas, el poder espiritual y el poder temporal: regali namque et ecclesiastica sibi mancipari et manu tener $i^{101}$. El concepto de "tiranía" que aquí maneja el maestro Gerardo es, por consiguiente, de raíz gregoriana y consiste básicamente en la impía persecución de la Iglesia romana y no en consideraciones políticas de índole secular como atentar contra la Iustitia.

Parecido trato recibe el aliado del emperador, el arzobispo de Braga Mauricio Bourdin (elegido como antipapa con el nombre de Gregorio VIII), a quien se acusa agriamente de ser un incestuoso ídolo del tirano ${ }^{102}$, alguien a quien la violentia regis teutonicorum habría elevado al solio pontificio ${ }^{103}$. En este personaje, enemigo personal de Diego Gelmírez en su dura pugna por la preeminencia eclesiástica en el noroeste de España y también enemigo ideológico por su alineamiento con el partido imperial en la Querella de las

${ }^{100}$ Historia Compostelana, exordium, ed. lat. cit., p. 3 (ed. E. FALQUE, p. 64).

${ }^{101}$ Historia Compostelana, II, c. V, ed. lat. cit., p. 263 (ed. E. FALQUE, p. 306).

${ }^{102}$ Historia Compostelana, II, c. XV, ed. lat. cit., p. 284 (ed. E. FALQUE, p. 327); curiosamente, Mauricio era un monje cluniacense de origen francés, algo que, teóricamente, debería haberle situado en el otro bando.

${ }^{103}$ Historia Compostelana, I, c. CXVII, ed. lat. cit., p. 250 (ed. E. FALQUE, p. 290). 
Investiduras, se fusionan las dos fobias políticas de Gerardo de Beauvais. Veáse si no el trato dado por Gerardo a Pelayo Menéndez, sucesor en la mitra bracarense del efímero antipapa: se le califica sin más de idiota $^{104}$. Un desprecio que no obedece, como quiere Emma Falque, a la "sinceridad" del maestro Gerardo, ni tampoco a su "ingenuidad" como pretende López Alsina ${ }^{105}$. Es, más bien, prueba de un implacable designio de denigrar a los enemigos estratégicos e ideológicos de Gelmírez.

Helene Wieruszowski ha estudiado un ejemplo paralelo de aplicación en esos años del arquetipo tiránico a otro soberano enfrentado a la Iglesia, alguien demasiado consciente de las prerrogativas de la dignidad regia: Roger II de Sicilia. Su apoyo al cuestionado ¿papa? Anacleto II, elegido en 1130 en polémicas circunstancias, le valió la animadversión de los monjes de toda la Cristiandad latina. Y, especialmente, la del poderoso abad Bernardo de Claraval, cuya figura empezaba a hacer sombra al abad de abades de Cluny. San Bernardo, agudo polemista, va a emprender una eficaz "campaña de propaganda" contra Roger II cuyo eje principal es la acusación de ser un Rex tyrannus. En el pensamiento del abad cisterciense, como ocurre en la Historia Compostelana, el topos tiránico se asocia al del Rex impius (proyección hierocrática gregoriana) y no al del Rex iniustus (proyección isidoriana del mal gobierno secular). El único delito de Roger II es apoyar a un papa cismático y ser, por tanto, un invasor Imperii y un "perseguidor de la Iglesia", faltas que le convierten en indigno del trono (en el epistolario bernardiano se le menciona siempre como el usurpator siculo $)^{106}$.

En cuanto a Alfonso el Batallador, la otra "bestia negra" de Gelmírez, se puede decir que belligerum ("belicoso") es el adjetivo más laudatorio que le dedica el cronista. En aplicación del modelo literario ya descrito, se le moteja repetidamente de tyrannus, alguien dominado por la ilícita ambitio Regni. Aquí Gerardo de Beauvais saca a relucir sus mejores dotes de narrador para ofrecernos un retrato desolador de la tyrannidis aragonensis, un relato que ha denigrado de una forma duradera la imagen del Rey Batallador: cuántos y cuales daños había causado a los hispanos, escribe Gerardo,

${ }^{104}$ Historia Compostelana, I, c. CXVII, loc. cit.

${ }^{105}$ E. FALQUE, ed., Historia Compostelana, op. cit., p. 290, n. 796; F. LÓPEZ AlsinA, La ciudad de Santiago de Compostela en la Edad Media, Santiago de Compostela, 1988, p. 77.

${ }^{106}$ Helene WIERUSZOWSKI, Roger II of Sicily, Rex tyrannus, in Twelfih-Century Political Thought, "Speculum", 38 (1963), pp. 53-58. 
"encendido por el furor de su tiranía, a saber: las cosas divinas y las humanas audazmente profanadas, las iglesias de España gravemente perturbadas, los tesoros de las iglesias violentamente arrebatados, y sus heredades y predios expoliados, los caudillos y todos los jefes de Iberia, unos hechos prisioneros por él mismo y cargados de cadenas, otros aniquilados por las espadas, los pobres muertos a hierro, de hambre o de frío, los mismos sacerdotes del Señor, los propios obispos, los maestros de las iglesias, cautivos como ladrones y salteadores, expulsados de sus sedes y afligidos por diversos ultrajes" ${ }^{107}$.

Este pasaje, de sobra conocido por los medievalistas, ha de ser contemplado bajo una nueva perspectiva que supere la mera descripción de los acontecimientos. Lo cierto es que el discurso histórico de la tiranía tenía en el Medievo muchas convenciones retóricas que el cronista compostelano sigue aquí a rajatabla. Precisamente, las "devastaciones" apocalípticas que del paso del ejército del Batallador pinta Gerardo afectaron particularmente al clero, como el propio cronista deja vislumbrar. Hay, es cierto, una alusión a los pauperes, "muertos a hierro", de hambre o de frío, pero es apenas una línea en la larga lista de acusaciones. En cuanto a los Hiberiae heroes, artificio literario que denota a los nobles leoneses y castellanos del bando antiaragonés (de nuevo nos encontramos con el motivo cluniacense de la heroización nobiliaria), el reseñar que fueron cargados de cadenas o aniquilados por la espada podría bien parecer un elogio al genio militar del Batallador si el que manejara la pluma fuera otro. No, ciertamente, lo que mueve la indignación de Gerardo es la Ecclesiae persecutio, que su mentalidad hierocrática asimila a la destrucción de España (in Hispania attritionem) ${ }^{108}$.

El retrato del "tirano aragonés" es completado con un episodio muy significativo. Amén de adornar al Batallador con una serie de epítetos despectivos (ferox, impius...), el cronista le va a negar la virtud de la Sapientia al relatar su entrevista con un legado pontificio, el abad de Chiusa. Al negarse el rey aragonés a acceder a las peticiones del legado papal y renunciar a su unión consanguínea con la reina Urraca, Gerardo de Beauvais glosa esta decisión con un pasaje del Liber Sapientiae Salomonis (I, 4): En el

\footnotetext{
${ }^{107}$ Historia Compostelana, I, c. LXXIX, ed. lat. cit., p. 138 (ed. E. FALQUE, p. 190).

${ }^{108}$ Historia Compostelana, I, c. LXXIX, loc. cit., p. 139.
} 
alma malévola no entrará la Sabiduría ${ }^{109}$. En definitiva, la imagen tiránica del Batallador no hubiera quedado completa sin una imagen sapiencial en negativo, la del Rex illitteratus en tanto que impius.

Ciertamente, Gerardo, magister y didascalus, otorgaba una cierta importancia al Ideal sapiencial en tanto que imagen positiva y legitimadora de los personajes que él consideraba dignos de un laus. Por ello, en la semblanza de su señor, el arzobispo Gelmírez, verdadero eje de la Historia Compostelana, va a prodigar epítetos sapienciales como prudens, providus o sapiens en tanto que eficaz mecanismo laudatorio. Raramente va a conceder estos epítetos sapienciales a otros personajes, ya sean clérigos o laicos ${ }^{110}$.

Gerardo de Beauvais traza, con unas pocas pinceladas, un retrato sapiencial del arzobispo en su juventud en un capítulo intitulado "de ingenio et moribus Didaci Episcopi": "fue un buen muchacho, instruido en las letras en la iglesia de Santiago y educado en la curia de este obispo"111. El conde de Galicia, Raimundo, va a elevarle a la dignidad de praepositus de la iglesia y señorío de Santiago al observar que "este joven era perspicaz, adornado de buenas costumbres y dotado de vivo ingenio" 112 . Así pues, la semblanza de Gelmírez se apoya en tres cualidades: eruditio in litteris, velox ingenium y bonae mores. Cualidades que, según el cronista, van a tener una repercusión en la actividad política del arzobispo compostelano.

Muerto el rey Alfonso VI, cuando la tierra era devastada por la guerra, el arzobispo de Compostela aparece ante los atribulados gallegos como el sucesor natural de la autoridad regia, tan rebajada en los días de la débil reina Urraca. Y ello merced a que "era hombre de esclarecido ingenio, prudente en sus consejos, discreto en su juicio, veraz y fervoroso en su celo de justicia"113. Así, la reina doña Urraca va a verse obligada a entenderse con

${ }^{109}$ Historia Compostelana, I, c. LXXIX, loc. cit., p. 139: "In malivolam animam non intrabit Sapientia" (ed. E. FALQUE, p. 191).

${ }^{110}$ Una de las raras ocasiones en que lo hace es cuando al papa Urbano II se le califica admirativamente como providentissimus episcopus al reseñarse la convocatoria del Concilio de Clermont (Historia Compostelana, I, c. V, ed. lat. cit., p. 20).

${ }^{111}$ Historia Compostelana, II, c. II, ed. lat. cit., p. 254 (ed. E. Falque, p. 299).

${ }^{112}$ Historia Compostelana, II, c. II, loc. cit., p. 255 (ed. E. FALQUE, p. 299).

${ }^{113}$ Historia Compostelana, I, c. XLVII, ed. lat. cit., p. 97 (ed. E. FALQUE, pp. 154-155): "ingenio clarum, consilio providum, ratione discretum, veracem et rectitudinis zelo ferventem". 
él en 1123, debido a que la prudentia de Gelmírez le era muy necesaria ${ }^{114}$. Y es que, según apostilla el maestro Gerardo, el consilium y auxilium del arzobispo eran precisos para dominar el reino de Galicia, pues su prudencia y su poder sobresalían muy alto ${ }^{115}$. Esta pareja prudentia-potentia forma parte del giro literario latino Fortitudo-Sapientia, una dualidad de virtudes muy utilizada desde la Antigüedad para retratar moralmente a un personaje. Quince años más tarde, enfrentado al hijo de Urraca, el ya anciano Gelmírez dudaba en si excomulgar a su antiguo pupilo, el emperador Alfonso VII. Pero, en palabras del cronista (que probablemente ya no era Gerardo), el arzobispo de Compostela era, en su senectud, providus, discretione et sapientia floridus, y escogió "sabiamente" no provocar la ira regia, nuntia mortis ("mensajera de la Muerte") $)^{116}$.

Frente a este acabado perfil sapiencial de Diego Gelmírez, nos encontramos con un único ejemplo paralelo de aplicación del arquetipo del Rex sapiens en la crónica compostelana. En realidad, Alfonso VI va a ser el príncipe mejor tratado, de largo, por el taller historiográfico compostelano. En su persona se van a acumular sucesivas imágenes del optimus princeps, en una cantidad tal, que el capítulo dedicado a ello es, en sí mismo, un pequeño speculum principis. En efecto, pareciera como si Gerardo de Beauvais que toma justo aquí la pluma para sustituir a Munio Adefonsiades, quisiera abrir su parte de la crónica con un acabado retrato de un Rey por el que, sin duda, debía sentir profunda admiración.

Basta llevar a cabo una escueta enumeración de los arquetipos regios aplicados al rey Alfonso para comprobar la presencia de un modelo principesco de intencionalidad didáctica. En primer lugar se transmite la idea de que el reinado de Alfonso VI fue un periodo de paz en todo el reino, paz que terminaría abruptamente con su muerte, iniciándose un periodo de convulsiones: "tras su muerte, la fidelidad, como si nunca hubiese existido, es relegada y la paz que en otro tiempo había dominado el reino desaparece" ${ }^{117}$. Así pues, Alfonso encarnaría el arquetipo del Rex pacificus. Pero también el del Rex

\footnotetext{
${ }^{114}$ Historia Compostelana, II, c. LIX, ed. lat. cit., p. 382 (ed. E. FALQUE, p. 411).

${ }^{115}$ Historia Compostelana, II, c. LIX, loc. cit.: "quippe cuius prudentia, cuius potentia altius eminebat". 596-597).

${ }^{116}$ Historia Compostelana, III, c. LIV, ed. lat. cit., pp. 594-595 (ed. E. FALQUE, pp.

${ }^{117}$ Historia Compostelana, I, c. XLVII, loc. cit.
} 
catholicus, ya que sería admirable por la "virtud de su santidad": Qui nimirum Rex mirae sanctitatis virtute conspicuus ${ }^{118}$. Esta sanctitas regis se ve reflejada en la liberación de muchos lugares en poder de los ismaelitas por obra de su "invicta espada"119, lugares reconquistados en los que edificó iglesias que se consagraron al culto divino. El perfil del rey piadoso se apoya, pues, en dos pilares: la pugna pro fidei y la construcción de iglesias.

Ahora bien, lo que más nos llama la atención de este perfil de príncipe cristiano ideal, luz y escudo de las tierras de España, es la atribución a un gobernante laico de cualidades sapienciales, algo, en principio, bastante ajeno al espíritu cluniacense. Gerardo de Beauvais habla sin reparos de la scientia regis Adefonsi (así intitula el capítulo), de la admirable capacidad de su ferventis ingenius y, finalmente, de su sapientia, una virtud que alinea con otras como la humildad y la discreción ${ }^{120}$.

En fin, resulta bastante complejo explicar la aparente contradicción que supone esta exaltación regia en una crónica y en un cronista, como Gerardo de Beauvais, quien, como hemos visto, es más bien reacio a todo lo que signifique una Realeza fuerte y autosuficiente. Evidentemente, la explicación podría encontrarse en los favores concedidos por Alfonso VI al clero, al rito romano y a la Orden de Cluny. Desde luego, la suya era la figura regia del pasado más facilmente asumible por un clérigo progregoriano como el maestro Gerardo. Por otro lado, la exaltación de la figura del conquistador de Toledo facilitaba el claroscuro con los años de devastación y ruina que habría acarreado a los reinos de León y Castilla el "tirano aragonés". La mitificación de Alfonso como Rex pacificus obedecería, de esta forma, a una maniobra más de denigración del Batallador.

No obstante, hay algo más. Cuando Gerardo escribe sobre la scientia regis de Alfonso VI no se refiere a que fuera un Rex eruditus. No, lo que pretende, ante todo, es dar a entender que gobernó "sabiamente" sus reinos. ¿Y cómo gobernó? Escuchemos la versión de Gerardo: "Y en el gobierno de sus súbditos... no se complacía en su excepcional y elevada posición, sino que

${ }^{118}$ Historia Compostelana, I, c. XLVI, ed. lat. cit., p. 94. En la edición de Emma Falque, muy correcta en líneas generales, se obvia inexplicablemente la traducción de esta virtud regia. Así, su traducción sería: "este rey, destacado por la virtud de su notable dignidad" (p. 152), lo que no hace justicia al espíritu del texto.

${ }^{119}$ Historia Compostelana, I, c. XLVI, loc. cit., p. 95 (ed. E. FALQUE, p. 152).

${ }^{120}$ Historia Compostelana, I, c. XLVI, loc. cit. 
él mismo creía en la igualdad de la condición humana . Sabía que si despreciaba a sus súbditos, iguales a él por naturaleza o no los gobernaba como convenía, ofendería gravemente por todo ello al Rector de toda la Creación, ante el cual todos somos iguales por naturaleza ${ }^{121}$. En el análisis de este pasaje hay que ser extremadamente cuidadosos y prestar enorme atención a los matices. Parece evidente, si nos ubicamos correctamente en el momentum histórico-ideológico del siglo XII, que esta proclama de gobierno igualitarista no tiene nada que ver con consideraciones presentistas que nos invitarían a pensar en el pueblo llano. Muy posiblemente, Gerardo de Beauvais, hijo de su tiempo, pensaba en la nobleza y el clero cuando escribía que el rey Alfonso gobernaba siendo muy consciente de que había súbditos suyos que eran sus aequales natura.

Esta precisión explicaría el siguiente pasaje del capítulo: "Por lo que, con qué justa y templada moderación exigía de sus súbditos lo que se le debía a su poder o cómo vivió en paz entre ellos ('pacificus extiterit'), lo mostraron abiertamente después de su muerte la ruina de los nobles y las guerras que siguieron"122. Por tanto, la nobilium pernicies, "la ruina de la nobleza", es aquí el concepto fundamental que baraja Gerardo. Y es que, posiblemente, tenía in mente al sector nobiliario cuando alababa la temperatio con que reinaba Alfonso VI, una templanza que consistiría en contar con el auxilium y el consilium del clero y la nobleza, con lo que se señalaba a los lectores una edad de oro en la cual un Rex pacificus gobernaba en armonía con estos dos ordines. Aquí y sólo aquí residiría, en nuestra opinión, la explicación del laus regis con el que encabeza Gerardo de Beauvais sus capítulos.

\section{LA "CHRONICA ADEFONSI IMPERATORIS": MÁXIMO EXPONENTE HISPÁNICO DEL MODELO CLUNIACENSE DE REALEZA}

El caso de la Chronica Adefonsi Imperatoris, dados sus contenidos y las circunstancias que envuelven su redacción, resulta ser el más paradigmático del ciclo historiográfico cluniacense. Una crónica que, si prestamos

\footnotetext{
${ }^{121}$ Historia Compostelana, I, c. XLVI, loc. cit.

${ }^{122}$ Historia Compostelana, I, c. XLVI, loc. cit.
} 
oídos a la teoría de Ángel Ferrari, había sido compuesta por Pedro de Poitiers, un monje cluniacense francés en quien no encontramos a un monje negro cualquiera sino nada menos que el secretario personal de Pedro el Venerable, abad de abades de Cluny ${ }^{123}$. Otro posible autor pudo haber sido Arnaldo, obispo de Astorga entre el 1144 y el 1153. Pero dado que también era francés y cluniacense no cambiarían mucho las circunstancias de la redacción de la Chronica Adefonsi ${ }^{124}$. Lo que sí es significativo es que el francés Arnaldo portara la mitra de Astorga, silla episcopal que ya habían ocupado los dos últimos cronistas del ciclo hispanomozárabe: el gramático Alón (posible alter ego del Silense como ya se ha dicho) y el notario Sampiro $^{125}$. No obstante, como veremos, las coordenadas del discurso histórico de Arnaldo difirieron sustancialmente del de sus antecesores en la cathedra asturicensis.

Estas coordenadas son, en palabras de Ángel Ferrari, la de "un retrato universalmente válido y ejemplar de gobernante cristiano supremo, según se entendía a la sazón la verdad universal, como secuela de la Verdad absoluta definida por el dogma trinitario" ${ }^{126}$. En un reciente trabajo sobre el discurso político de la Chronica Adefonsi Imperatoris, Isabel Las Heras opina, en este sentido, que el cronista "le da un marcado carácter apologético que manifiesta las líneas rectoras de la política imperial" ${ }^{127}$. Es la Chronica, pues, una obra historiográfica de un marcado cariz apologético, un exemplum principis cluniacense, cuyas ideas iban dirigidas, como señala Las Heras, al "círculo de poder" hispano del siglo XII ${ }^{128}$.

${ }^{123}$ Vid. Ángel Ferrari, El cluniacense Pedro de Poitiers y la "Chronica Adefonsi Imperatoris", "Boletín de la Real Academia de la Historia", 153 (1963), pp. 153-204.

${ }^{124}$ L. SÁNCHEZ BELDA, Chronica Adefonsi Imperatoris, ed., Madrid, 1950, p. XX; Antonio UBIETO, Sugerencias sobre la Chronica Adefonsi Imperatoris, "Cuadernos de Historia de España", 25-26 (1957), pp. 325-326.

${ }^{125}$ Vid. A. QUINTANA PRIETo, Sampiro, Alón y Arnaldo. Tres obispos de Astorga, cronistas del reino de León, "León medieval. Doce estudios", León, 1978, pp. 59-68.

${ }^{126}$ A. FERRARI, Artificios septenarios en la "Chronica Adefonsi Imperatoris" y "Poema de Almeria" "Boletín de la Real Academia de la Historia", 153 (1963), p. 20.

${ }^{127}$ Isabel LAS HERAS, Temas y figuras bíblicas en el discurso político de la "Chronica Adefonsi Imperatoris", "El discurso político en la Edad Media", ed. N. GuGLIELMI y A. RUCQUOI, Buenos Aires, 1995, p. 118.

${ }^{128}$ I. LAS HERAS, Temas y figuras bíblicas, art. cit., p. 119. 
Su condición cluniacense la deduce el profesor Ferrari de dos pruebas de carácter heurístico, su tratamiento de las diversas rebeliones contra el monarca y de las relaciones con los musulmanes (reflejo de una visión cruzadista de la Reconquista ajena a la tradición propiamente hispánica), y una de carácter hemenéutico: la constatación de la aplicación de un esquema tipológico trinitario (esto es, una aritmología artificiosa que ordena de forma trinitaria la narración), operativo en la Chronica, semejante al que se observa en la obra del mencionado secretario del Venerable, Pedro de Poitiers ${ }^{129}$.

Consolidada la figura del rey Alfonso VI como optimus princeps merced a la Historia Compostelana, sería lógico suponer que la Chronica Adefonsi Imperatoris tendría como objetivo erigir al nieto en un digno epígono de la grandeza del conquistador de Toledo. Sin embargo, el clérigo autor de la Chronica Adefonsi se va a mostrar más bien tímido a la hora de ensalzar a su biografiado, a pesar de la indudable alianza estratégica que el emperador estableció con la Iglesia. Así, en opinión de Esther Pascua, "la política de Alfonso VII pasa por engrandecer y acrecentar el poder de los eclesiásticos convirtiéndolos en pieza impres- cindible de la organización política del Reino" ${ }^{130}$. Esta alianza con la Iglesia tuvo un reflejo menor en la Chronica Adefonsi, en la que el protagonismo político sólo es otorgado con cuentagotas al biografiado. Ahora bien, no cabe duda de que se inserta en el marco de lo que la propia Esther Pascua ha definido con acierto como "actividad ideológica de la Iglesia destinada a presentar la figura del Rey como justa y restauradora de la paz" ${ }^{131}$.

Isabel Las Heras ha puesto de relieve que son las imágenes bíblicas las que más se aplican al perfil regio de Alfonso VII. No obstante, hay que señalar que estas imágenes bíblicas van a ser también utilizadas para ensalzar a distintos nobles en un contexto de "monarquización" nobiliaria. La imagen bíblica del emperador más clara y rotunda la hallamos en una asimilación de éste con el rey David, en un marco en el que se establece una dicotomía con

\footnotetext{
${ }^{129}$ A. Ferrari, El cluniacense Pedro de Poitiers, art. cit., pp. 154 y ss.

${ }^{130}$ Esther PASCUA, Hacia la formación política de la Monarquía medieval. Las relaciones entre la Monarquía y la Iglesia castellano-leonesa en el reinado de Alfonso VII, "Hispania", 172 (1989), p. 408.

${ }^{131}$ E. PASCUA, Hacia la formación política de la Monarquía, art. cit., p. 410; vid. también su artículo El respaldo ideológico de la Iglesia a Alfonso VII: los preámbulos y la "Chronica Adefonsi Imperatoris", "Universitas Tarraconensis", 8 (1985-1986), pp. 39-64, que incide en esta línea.
} 
la figura de Alfonso I el Batallador, quien es identificado a su vez con el rey Saúl ${ }^{132}$. Lo verdaderamente interesante aquí no es tanto la imagen davídica de Alfonso VII como la crítica implícita a la bestia negra de los cluniacenses, el Batallador, a quien ya veíamos denostado como Rex tyrannus en la Historia Compostelana. En efecto, Isabel Las Heras interpreta que al escribir el cronista que la casa del rey aragonés siempre estaba decreciendo mientras que la de Alfonso Raimundez iba en auge ${ }^{133}$, éste utilizaba un episodio bíblico que subliminalmente señalaba al Batallador como alter ego de un rey inicuo, Saúl, a quien Dios había vuelto la espalda, designando un sucesor en la persona de David cuyo papel haría Alfonso VII.

A tenor de esto, no resulta fácil en principio explicar el posterior laudo funerario que el cronista lleva a cabo de la figura del Rey Batallador ("no hubo entre los anteriores reyes aragoneses ninguno igual a él en fortaleza y prudencia" ${ }^{134}$ ), laudo sapiencial aderezado con una escenificación del llanto del pueblo aragonés por el rey muerto que tiene resonancias del Libro de los Macabeos $^{135}$. Ahora bien, tanto el elogio funerario como la utilización de la imagen macabea pueden tener su explicación en un cambio de actitud del cronista hacia el soberano aragonés, quien, al final de su reinado, habiendo renunciado al Imperio hispánico, ya no representaba una amenaza para los intereses cluniacenses en León y Castilla. Como señala Isabel Las Heras, la condena implícita en la identificación del Batallador con Saúl y Antíoco Epífanes (el monarca seleúcida que saqueó el templo de Jerusalén, alegoría de las devastaciones de la hueste del aragonés en Castilla), es matizada al final de la crónica con estos elogios aparentemente contradictorios ${ }^{136}$.

A decir verdad, la única escena de la crónica que encaja en la dimensión salvífica que tanto Ángel Ferrari como Isabel Las Heras han detectado en la figura del emperador que dibuja Arnaldo de Astorga, tiene lugar con ocasión de su coronación imperial. Aquí sí encontramos algún

\footnotetext{
${ }^{132}$ I. LAS HERAS, Temas y figuras bíblicas, art. cit., p. 124. cit.).

${ }^{133}$ Chronica Adefonsi Imperatoris, I, 17 (apud I. LAS HERAs, Temas y figuras bíblicas, loc.

${ }^{134}$ Chronica Adefonsi Imperatoris, I, 58 (apud I. LAS HERAS, Temas y figuras bíblicas, art. cit., p. 127).

${ }^{135}$ Chronica Adefonsi Imperatoris, I, 61: Heu rex! Quomodo cecidisti qui salvos nos faciebas! (apud I. LAS HERAS, Temas y figuras bíblicas, art. cit., p. 127, n. 25).

${ }^{136}$ I. LAS HERAS, Temas y figuras bíblicas, loc. cit.
} 
atisbo de mesianismo regio, especialmente en la descripción de los cánticos del Te Deum laudamus y los detalles de la ceremonia de coronación ${ }^{137}$. No obstante, hay que recordar que esta escena apenas tiene aditamentos ni adjetivaciones laudatorias, sino que es una descripción bastante fiel de un acontecimiento que realmente tuvo lugar. Las glosas elogiosas que el Silense añade a una escena similar en el caso de Fernando I brillan aquí por su ausencia. Entiéndase esto bien, no queremos dar a entender que el cronista despreciara o no valorara la figura del emperador de las Españas. El hecho mismo de que decidiera escribir esta obra es señal de su admiración por Alfonso Raimundez. Sin embargo, dentro de su mentalidad cluniacense y feudalizante, no considera que el emperador sea el protagonista absoluto de su reinado ni que se deban cargar las tintas en el laudo de su figura. Como vamos a comprobar enseguida, Arnaldo de Astorga va a conceder en su obra un protagonismo a la nobleza castellanoleonesa casi paralelo al de la Realeza.

Por lo demás, a lo largo de la Chronica Adefonsi Imperatoris nos encontramos con un único pasaje de índole inequívocamente especular (esto es, que aluda a las cualidades personales del emperador). $\mathrm{Y}$ este pasaje aparece, curiosamente, puesto en boca de un rey andalusí: "Y después que el rey Zafadola vió la sabiduría y las riquezas del rey de León y una gran paz en su palacio y en todo su Reino le dijo: 'son ciertas las palabras que sobre tí oí en Rueda acerca de la sabiduría y de la misericordia que hay en ti, de la paz que hay en tu Reino y de tus riquezas. Felices tus hombres y felices tus nobles consejeros, los que habitan contigo y los que están en tu reino'"'138.

Como se puede comprobar, este pasaje reúne en sí mismo una completa enumeración de las virtudes regias, conteniendo asimismo un abierto laus regis de la persona de Alfonso VII. ¿Quién entre los reyes se asemeja al

\footnotetext{
${ }^{137}$ Chronica Adefonsi Imperatoris, I, 70 (ed. Maurilio PÉREZ, León, 1997, pp. 55-56): “et induto rege capa optima, miro opere contexta, imposuerunt super caput eius coronam ex auro mundo et lapidibus pretiosis, et misso sceptro in manibus eius... una cum episcopis et abbatibus deduxerunt ante altare Sancte Marie cantantes Te Deum laudamus" usque ad finem et dicentes Vivat Adefonsus Imperator!".

${ }^{138}$ Chronica Adefonsi Imperatoris, I, 29 (ed. cit., p. 73): “Sed postquam rex Zafadola vidit sapientiam et divitias regis Legionis et magnam pacem in palatio suo et in omni regno eius dixit ei: 'Verus est sermo quem audivi de te in Rota, de sapientia et de misericordia , quae est in te, et de pace quae est in regno tuo, et de divitiis tuis: beati viri tui et beati principes tui, qui tecum habitant et qui sunt in regno tuo'" (ed. cit. L. SÁNCHEZ BELDA, p. 27).
} 
rey de León?, exclama ${ }^{139}$. El emperador de las Españas encarnaría varios arquetipos, según las palabras del rey moro de Rueda que el cronista se ingenió en componer: el del Rex pacificus (la paz impera en sus dominios), el del Rex sapiens (ya hemos hablado de la significación de los atributos regios sapienciales), el del Rex misericors (topos repetido en otro pasaje, en el que se alaba el buen corazón de Alfonso al perdonar al conde Gonzalo ${ }^{140}$ ) y el del Rex dives (cuya derivación moral en las mentalidades de la Feudalidad sería la de la largueza regia, la liberalitas regis).

En consonancia con el magro contenido especular del retrato regio perfilado en la Chronica Adefonsi Imperatoris, su colofón, el Poema de Almería, concentra sus más acabadas imágenes del poder en tres nobles de la comitiva regia en lugar de hacerlo en la propia persona del emperador. Como apunta Isabel Las Heras, el cronista ya se complació en aplicar en el cuerpo central de la Chronica Adefonsi Imperatoris imágenes bíblicas a nobles como el frontero Munio Alfonso o los alcaides toledanos Rodrigo Fernández y Rodrigo González de Lara, comparados con los hermanos Macabeos ${ }^{141}$.

De esta forma, del illustris miles asturiano Pedro Alfonso, se nos dice en el Poema de Almería que sobresale entre todos por sus virtudes. Resplandece por su honradez y supera en probidad a sus iguales. Es hermoso como Absalón, vigoroso como Sansón, y, versado en el bien, posee el saber de Salomón ${ }^{142}$. No es de extrañar, pues, que, en consonancia con esta imagen, el cronista afirme que el emperador le respetaba como a un igual. El laus que le dedica él mismo es más propio de un rey que de un simple noble. Más aún si cabe si observamos que no hay un retrato semejante dedicado al propio imperator Hispaniarum.

${ }^{139}$ Chronica Adefonsi Imperatoris, I, 28, ed. cit., p. 73: "Quis similis regi Legionensi in regibus?" (ed. lat. cit., p. 27).

${ }^{140}$ Chronica Adefonsi Imperatoris, I, 45 (ed. esp. cit., p. 77): "Y el rey le recibió pacíficamente, le dirigió las mejores palabras y como dice el hagiografo: el corazón de los reyes y el curso de las aguas en la mano del Señor (cor regum et cursus aquarum in manu Domini").

${ }^{141}$ I. LAS HERAS, Figuras y temas bíblicas, art. cit., pp. 128-129.

${ }^{142}$ Chronica Adefonsi Imperatoris, "Poema de Almería", vv. 126-134 (ed. cit., p. 135): "Dux fuit illustris istis Petrus Adefonsi, / nondum consul erat, meritis tamen omnibus est par, $;$ est nulli moestus, in cunctis erat honestus, / fulget honestate, superatque pares probitate, / pulcher ut Absalon, virtute potens quasi Sanson, / instructisque bonis, documenta tenet Salomonis" (ed. lat. cit., p. 172). 
Algo similar sucede con el conde leonés Ramiro Fruela, alférez del emperador. El cronista alaba en él no sólo su prudencia y afabilidad sino también escribe: "notable por su belleza, descendiente de estirpe real, es amado por Cristo al observar el gobierno de las leyes. Flor entre las flores, protegido también con la fortaleza de los buenos, diestro en las armas, todo lleno de amabilidad, influyente en el consejo, ilustre por su justo gobierno, precede a todos los obispos en el séquito de los reyes" ${ }^{\text {143 }}$. Otro retrato digno de un rey.

Pero nuestra sorpresa aumenta al comprobar que el mayordomo del emperador, el conde Ponce, noble lanza, recibe un elogio aún más entusiasta. Él reúne en su persona, afirma el cronista, una serie de virtudes bíblicas tales como la fuerza de Sansón y la espada de Gedeón, siendo igual a Jonatás e ilustre como Josué. Pero Arnaldo de Astorga se complace en utilizar también comparaciones con los héroes clásicos del tipo "jefe de su pueblo como Héctor, generoso y veraz como el invencible Ayax"144.

En consecuencia, la "heroización" nobiliaria de resabios épicos ya entrevista en la Historia Roderici y la Compostelana, parece alcanzar en estos versos del Poema de Almería su máxima expresión, poniéndose en juego giros tanto bíblicos, como latinos ${ }^{145}$. Fijémonos sí no en la descripción del héroe guerrero: "no cedía ante nadie, nunca retrocedía en el combate; su diestra hiere con fuerza; cuando su voz resuena, el enemigo cae derribado. Cuando da consejos, se explaya el cronista, posee la sabiduría de Salomón"146. De nuevo, la apelación a la imagen sapiencial salomónica en un laico que no es

\footnotetext{
${ }^{143}$ Chronica Adefonsi Imperatoris, "Poema de Almería", vv. 100-110 (ed. cit., p. 134): "Hos Radimirus sequitur comes ordine mirus, / prudens et mitis Legionis cura salutis. / Forma praeclarus, natus de semine regum, / est Christo charus servans moderamina legum. / In cunctis horis iussum tenet imperatoris, / pervigili cura, cui servit mente benigna; flos erat hic florum, munitus et arte bonorum, / armis edoctus, plenus dulcedine totus, / consilio pollens, iusto moderamine fulgens, / pontifices omnes praecedit in ordine legum, / exuperatque pares trucidando cacumina regum" (ed. lat. cit., pp. 170-171).

${ }^{144}$ Chronica Adefonsi Imperatoris, "Poema de Almería", vv. 176-181 (ed. cit., p. 137): "Pontius ista comes regit agmina nobilis hasta, / virtus Sansonis erat hic, gladius Gedeonis; I compar erat hic, gladius Gedeonis; / compar erat Ionathae, praeclarus uti Jesus nave. / Gentis erat rector, sicut fortissimi Hector. / Dapsilis et verax, velut insuperabilis Ayax" (ed. lat. cit., p. 175).

${ }^{145}$ Vid. Salvador MARTínez, El "Poema de Almería" y la épica románica, Madrid, 1975.

${ }^{146}$ Chronica Adefonsi Imperatoris, "Poema de Almería", vv. 182-190 (ed. cit., p. 137): "non cuiquam cedit, numquam bellando recedit. Non vertit dorsum, nunquam fugit ille retrorsum... I ... dextra ferit fortis, resonat vox, sternitur hostis. / Cum dat consilium documenta tenet Salomonis" (ed. lat. cit., p. 176).
} 
el propio emperador. Sospechosa reiteración, inusual e iconoclasta por cuanto tiene de menosprecio para la figura regia, lo que nos inclina a opinar que el autor de la Chronica Adefonsi no era precisamente partidario de una monarquía fuerte y autosuficiente. Lo cual, creemos que encajaría a la perfección con su perfil cluniacense.

La verdad es que la única concesión al laus regis en el Poema de Almería es la mención, delatadora de la mentalidad política de un cluniacense francés, a la dignitas imperialis de Alfonso VII como un lazo de unión con la legendaria figura de Carlomagno, cuyas hazañas emularía el emperador de las Españas en opinión del cronista, dado que "fueron iguales en carácter, parejos en la fuerza de las armas e igual fue la gloria de las guerras realizadas por ellos"147. He aquí un ejemplo de la vinculación existente entre la mitificación del nomen imperialis y el topos del Carolus redivivus, impulsado con fuerza en esos años tanto por los Capeto como por los Staufen (Federico Barbarroja haría canonizar al emperador franco en Aquisgrán pocos años después de la muerte de Alfonso VII) ${ }^{148}$.

En los esquemas mentales de un monje cluniacense francés la figura de Carlomagno representaba el summum del arquetipo regio y pareciera que el cronista da a entender que la dignidad imperial asumida por Alfonso Raimundez le hubiera transmitido algo del carisma y las virtudes regias del emperador franco de Occidente. Significativamente, para el cronista la dignidad imperial que aquí cuenta no es la procedente de la tradición imperial leonesa sino aquella homologable con el Imperium Romanum. El contraste, por poner un ejemplo, con el Silense, un hispano mozarabizante tan antifrancés como enemigo de la figura de Carlomagno (al que no se recataba, como ya vimos, de retratar como frívolo y corrupto con ocasión de su retirada de España), es palmario ${ }^{149}$.

Se podría decir que tan elevada y augusta comparación casi compensa el ninguneo al que Alfonso VII es sometido en lo que se refiere a la

\footnotetext{
${ }^{147}$ Chronica Adefonsi Imperatoris, "Poema de Almería", vv. 17-20 (ed. cit., p. 131): "Hic Adefonsus erat nomen tenet imperatoris, / facta sequens Caroli, cui competit aequiparari. / Gente fuere pares, armorum vi coaequales. / Gloria bellorum gestorum par fuit horum" (ed. lat. cit., p. 166).

${ }^{148} \mathrm{Vid}$. a este respecto José Manuel NIETO SORIA, El Imperio medieval como poder público: problemas de aproximación a un mito político, "Poderes públicos en la Europa medieval", XXIII Semana de Estudios Medievales, Estella, 1996, pp. 421-423.

${ }^{149}$ Historia Silense, 18, op. cit., ed. cit., p. 164.
} 
enumeración preceptiva de sus virtudes regias. En cualquier caso, se echan de menos las siempre socorridas comparaciones con reyes bíblicos y héroes homéricos ${ }^{150}$ que el cronista prodiga a manos llenas, como hemos podido comprobar, con otros personajes contemporáneos de Alfonso Raimundez.

De un modo muy particular, Ferrari se dió cuenta de esta ausencia del laus regis en el Poema de Almería. Incluso, insinúa que se haya podido perder el fragmento que contendría este laus, dado que, dentro de la lógica inherente a la compleja numerología que él descubrió en el esquema narrativo de la Chronica, correspondía al apartado segundo del Poema cantar las grandezas de Alfonso VII conforme al atributo de lo que califica como Espíritu del Padre (en el marco de la oscura cábala teológica que Ferrari entrevió en la Chronica, la virtud de la preservación del orden corresponde a la parte de la obra consagrada a la Primera Persona de la Trinidad $)^{151}$. Sin embargo, este laus del emperador no aparece por ninguna parte. Y es que, pese a que Ferrari quiere ver en la Chronica una apología de un emperador mesiánico, "un nuevo Mesías que ejecuta la voz de Cristo a la Humanidad doliente" 152 y a la que redime con sus campañas contra el Infiel en $\mathrm{Al}$ Andalus, lo cierto es que este pretendido mesianismo regio no pasa, en nuestra opinión, de ser una construcción artificiosa de alguien tan brillante como lo fue el profesor Ferrari, empeñado en ver en la Chronica Adefonsi Imperatoris una obra cumbre de la literatura apologética medieval ${ }^{153}$.

Este retrato ejemplar del gobernante cristiano se reproduce, de forma mucho más concisa claro está, en la documentación cancilleresca del emperador. En particular, el último de los cancilleres de Alfonso VII, Pedro, se encargará de hacer patente el perfil regio que aspiraba a encarnar su señor. Así, el rey Alfonso sería "pius, felix, inclitus, triumphator et semper invictus tocius Hispaniae divina clementia famossisimus imperator" ${ }^{154}$. Valores como,

${ }^{150}$ Vid. Maurilio PÉREZ, Influencias clásicas y bíblicas en la Chronica Adefonsi Imperatoris, “Actas del I Congreso Nacional de Latín medieval”, ed. M. PÉREZ, Léon, 1995, pp. 349-355.

${ }^{151}$ A. FERRARI, Artificios septenarios, art. cit., p. 63.

${ }^{152}$ A. FERRARI, Artificios septenerios, art. cit., p. 66.

${ }^{153}$ A. FERRARI, Artificios septenarios, art. cit., p. 67: "ningún otro ejemplar tipológico occidental de este género, entre los que existen, es parangonable en exactitud y belleza, según las entendía la estética medieval, con la Chronica Adefonsi Imperatoris"

${ }^{154}$ Manuel RECUERO, Alfonso VII, Emperador. El Imperio hispánico en el siglo XII, León, 1979, p. 193. 
por un lado, la fama y el prestigio (inclitus, famossisimus), y, por el otro, la pericia bélica y la victoria (invictus, triumphator) predominan aquí sobre las otras consideraciones que veíamos apuntadas en la Chronica. Y es que, en efecto, este escueto retrato cancilleresco se ajustaba mucho más a la imagen que el propio emperador tenía de sí mismo: afamado y victorioso. ¿Qué más podía anhelar un rey guerrero, impregnado de la mentalidad propia de la Feudalidad borgoñona importada a Castilla por su padre y su tío? Ello de acuerdo con el esquema trifuncional francoborgoñón que otorgaba al Rey funciones propias de la militia que le abocaban a la tutela doctrinal propia de los iuvenes.

Esto confirma que las palabras del rey Zafadola en la Chronica Adefonsi Imperatoris acerca del emperador en tanto que Rex sapiens o Rex pacificus no son sino una construcción especular del autor, un exemplum cargado de ideología política y, ni mucho menos, el retrato biográfico de Alfonso Raimundez. ¿Y qué decir de la exaltación de sabor bíblico llevada a cabo con los condes Ponce y Pedro Alfonso? Aquí, aparte de la probable amistad que el obispo Arnaldo de Astorga sintiera hacia estos nobles, el voluntarismo didáctico y ejempla- rizante propio de un espejo de príncipes se impone sobre cualquier otra consideración narrativa y el autor de la Chronica da rienda suelta a su pluma para construir una imagen completamente artificiosa de un miles emeritus.

\section{EL CASTELLANISMO FILONOBILIARIO DE LA "CHRONICA NAIERENSE"}

El Liber chronicorum ab exordio Mundi, una crónica con vocación frustrada de historia universal, fue compuesto hacia el año 1160 en el scriptorium de Santa María de Nájera por un monje cluniacense, posiblemente de origen francés ${ }^{155}$. Los dos primeros libros carecen de interés a efectos de la investigación que nos ocupa, tanto por su ámbito cronológico como por el hecho de que el monje najerense se dedicó a copiar casi íntegramente a los cronistas que le habían precedido como la Crónica de Alfonso III, la Crónica Albeldense o las ya mencionadas obras del Silense y Sampiro.

${ }^{155}$ C. OrCÁstegui; E. SARASA, La Historia en la Edad Media, op. cit., p. 202. 
El tercer libro (de nuevo, el esquema trinitario) aborda, desde una óptica castellanista, el periodo 1037-1109. Como ya avanzamos al abordar la Historia Roderici, es aquí donde la Chronica Naierense se engarza perfectamente en la tradición historiográfica cluniacense. $\mathrm{Al}$ incorporar el ciclo épico cidiano o la leyenda de Fernán González, el monje negro de Nájera va a cerrar el proceso de heroización nobiliaria iniciado por Jerónimo de Perigord. De su condición cluniacense apenas si hay otros indicios en el discurso histórico que presenta, exceptuando un breve pasaje del capítulo XXXVIII del tercer libro, donde al referir la petición de mediación en el conflicto con su hermano Sancho, efectuada por Alfonso VI al abad Hugo de Cluny, el cronista califica elogiosamente a la domus Cluniacensis como sanctissimus conventus ${ }^{156}$.

Lo cierto es que la Chronica de Nájera no es excesivamente enjundiosa en lo que toca al pensamiento político. El estilo lacónico, a veces telegráfico, del monje cronista acerca esta obra al género de los cronicones monásticos más cortos de miras y localistas. Poco dado a alegrías literarias, el monje najerense evita calificar los acontecimientos u otorgar epítetos, lo cual dificulta extraordinariamente conocer sus posturas políticas.

De su retrato de Fernando I, lo único que podemos deducir es que la imagen sapiencial que el Silense había levantado en torno a su figura no le disgustaba, dado que la reproduce ad litteram, tanto en lo que toca a la educación de sus hijos como en la ceremonia navideña de exaltación del Fernando como Rex eruditus ${ }^{157}$. Más creativo resulta ser respecto a Sancho II de Castilla. En uno de los pocos perfiles regios que se deben a su pluma, el Najerense escribe de este príncipe que era magnanimus, fortis y de acer ingenio $^{158}$. Un perfil regio que se completa cuando, al narrar las vísperas de la batalla de Vulpéjar entre Sancho II y Alfonso VI, el cronista, que deja ya ver abiertamente sus preferencias filocastellanas, describe la convocatoria de la curia regia al anochecer por parte de Sancho como algo propio de un rey sabio $^{159}$. Y es que en este breve pasaje el monje cronista aprovecha para

\footnotetext{
${ }^{156}$ Chronica Naierense, III, c. XXXVIII, ed. A. Ubieto, Valencia, 1966, p. 112.

${ }^{157}$ Chronica Naierense, III, c. XX y XXVIII, ed. cit., pp. 94 y 108.

${ }^{158}$ Chronica Naierense, III, c. XXIX, ed. cit., p. 110.

${ }^{159}$ Chronica Naierense, III, c. XXIX, ed. cit., p. 111: "In ipsa autem nocte que diem belli precedebat, quia iuxta quendam sapientem nox haber consilium, rex Santius, convocata magnatorum suorum parte..."
} 
deslizar unas cuantas nociones referentes al buen gobierno en la Realeza feudal: el Rey convoca el colloquium nocturno con los magnates porque desea el sanioris consilium (esto es, el consejo de los más cuerdos, de los más prudentes), un consejo que le permitirá conocer cual de los dos ejércitos en liza es el más numeroso y potente ${ }^{160}$.

Dentro de su línea procastellanista, el monje de Nájera va a describir entusiásticamente la victoria de Sancho II sobre los leoneses, con arenga a la hueste castellana por parte del Rey incluida. Una arenga en la cual el monje cronista, imbuido de ardor castellanista, puso en la boca de Sancho la siguiente proclama: si illi numerosiores, nos meliores et forciores ${ }^{161}$. En esta batalla aparece en escena ya la figura del héroe nobiliario castellano, Rodrigo Díaz de Vivar, cuya lanza comparo a la de cien leoneses. El resto de los capítulos del reinado de Sancho II, incluido el regicidio a traición cometido por Vellido Dolfos, está en consonancia con el ciclo épico cidiano, en el cual se asignaba a la infanta Urraca la instigación del crimen. Como han señalado Colin Smith y Salvador Martínez, la Chronica Naierense, a diferencia del resto de crónicas latinas del siglo XII, va a utilizar como fuente los cantares de gesta de la épica castellana (algunos hoy perdidos), especialmente el ya mencionado Carmen de morte Sanctii regis ${ }^{162}$.

El castellanismo filonobiliario del Najerense es tan agudo que le impide verter el menor elogio sobre Alfonso VI una vez este obtuvo el cetro, ni siquiera cuando impuso el rito romano o, lo que es más llamativo aún, cuando reseña la entrega a Cluny por parte del Rey del monasterio de Santa María de Nájera, hecho que le afectaba personalmente y que se limita a consignar en línea y media: Iste Aldefonsus sub era MCXVIII dedit monasterium Naiarum cluniacensibus monachis ${ }^{163}$. Y eso es todo. Evidentemente, el entusiasmo cidiano- castellanista del monje negro de Nájera era mucho más fuerte que sus convicciones políticas cluniacenses. ¿Fidelidad familiar nobiliaria? Quizá en sus orígenes familiares esté la respuesta.

\footnotetext{
${ }^{160}$ Chronica Naierense, III, c. XXIX, loc. cit.: “ ... que sanioris videbatur esse consilii, habuit cum eis consilium et colloquium, prescire volens cuius regis exercitus alterius exercitum vi et numero superaret".

${ }^{161}$ Chronica Naierense, III, c. XXIX, loc. cit.

${ }^{162}$ Colin SMITH, The Making of the Poema de Mio Cid, op. cit., pp. 44-52; Salvador MARTínEZ , Tres leyendas heroicas de la Najerense, art. cit., pp. 173-177.

${ }^{163}$ Chronica Naierense, III, c. L, ed. cit., p. 116.
} 
Ciertamente, en la imagen de Alfonso VI como Rex pacificus, muy parecida a la que hemos visto en la Historia Compostelana, encontramos la única concesión laudatoria del monje cronista a la figura del Rey de León y Castilla. El lacónico monje acuña ahora, en un alarde impropio de su estilo, la célebre imagen literaria de la mujer que podía atravesar los reinos de Alfonso VI cargada de oro y plata sin correr el más mínimo peligro ${ }^{164}$. Ahora bien, aunque es cierto que esta es una imagen positiva de paz y orden, hay que recordar que el Najerense la toma prestada, en líneas generales, del Chronicon del obispo Pelayo de Oviedo, dándole además una explicación poco halagüeña, una explicación que contrasta vivamente con la que daba Gerardo de Beauvais sobre la temperatio regis respecto a la nobleza. En efecto, el Najerense sostiene que es el temor a los castigos ejemplares de Alfonso VI, entre los cuales cita la defenestración de siete condes revoltosos, lo que impedía que no sólo los malhechores se movieran, sino que ni príncipes, ni caballeros, ni jueces, ni merinos, ni ricos, ni pobres se atrevieran a dar un solo paso en falso, tan grande era el temor que inspiraba la justicia sumaria del Rey ${ }^{165}$.

Bien pudiera ser que a la sensibilidad filonobiliaria del Najerense no le hiciera mucha gracia lo de defenestrar a siete condes en una sola jornada. Y es que, en el último capítulo de la Chronica, al narrar la muerte de Alfonso VI, tampoco aprovecha la ocasión para elaborar un retrato del monarca que ocupa los últimos capítulos de su obra. No, la única concesión que hace en su honor es un aislado y formulario gloriosus $\operatorname{Rex}{ }^{166}$, que no satisface, ni mucho menos, la curiosidad del lector con respecto a la personalidad del conquistador de Toledo.

\footnotetext{
${ }^{164}$ Chronica Naierense, III, c. LVII, ed. cit., p. 118: "Sed tanta pax fuit in diebus eius quod quelibet muliercula sola portaret aurum vel argentum per omnem terram regni eius, ita quod non inveniret qui eam tangeret.."

${ }^{165}$ Chronica Naierense, III, c. LVII, loc. cit.: "Tantum fuit terribilis quod nullus malefactor se auderet eius conspectui presentare. Nullus princeps, nullus miles, nullus maiorinus, nullus dives, nullus pauper de regno eius audebat in proximum litem aut rixam movere aut in aliquo inquietare".

${ }^{166}$ Chronica Naierense, III, c. LVIII, ed. cit., p. 119.
} 


\section{CONCLUSIÓN}

De todo lo expuesto se colige que nos hallamos ante un hito tan decisivo como poco estudiado en la evolución de la concepción de la Realeza en León y Castilla. La noción, propagada por algunos autores de un "desierto intelectual" en el siglo XII hispánico, ha de ser matizada, ya que la reforma cluniacense aportó a la cultura de los reinos hispánicos algo más que una mejora en el estilo literario latino. Ciertamente, al igual que había ocurrido en Francia con el episcopado de tradición carolingia un siglo antes, los monjes cluniacenses sustituyeron al episcopado de tradición isidoriana en tanto que creadores de ideología política y aportaron un programa político de corte gregoriano para la Realeza hispánica a través de un rico y fecundo ciclo historiográfico.

Un programa que será la última aportación significativa del monaquismo benedictino a la teoría política castellana, ya que en la segunda mitad del XII, las escuelas catedralicias y el episcopado van a sustituir a los monjes en el liderazgo intelectual del Reino. Sin embargo este nuevo liderazgo del clero secular no iba a producir frutos significativos hasta principios del siglo XIII, ni en el campo de la literatura, ni en el de la historiografía, ni en el de la publicística política. En cuanto a los cistercienses hispanos, su producción literaria fue mínima. Ahí radica la importancia de este ciclo historiográfico cluniacense, en su condición de única fuente para conocer el hasta ahora ignoto pensamiento político hispánico del siglo XII.

Un pensamiento político que, en líneas generales, tiene como principal característica la introducción de una imagen de la Realeza mediatizada por la tuitio clerical, mediatización cuya máxima expresión sería el arquetipo político del Rex tyrannus, algo que supuso, en el nivel ideológico, un fenómeno de una magnitud similar a hitos tales como la aplicación de la reforma monástica cluniacense, la adopción del rito romano o la penetración de las formas feudales borgoñonas. De forma paralela a esta imagen de una Realeza disminuida, que vendría a ser una suerte de "contramodelo" regio alternativo tanto al isidoriano del siglo XI como al soberanista del siglo XIII, se produjo una "monarquización" de la nobleza. Una "monarquización" reflejada en el surgimiento del ciclo épico castellano con su subyacente "heroización" nobiliaria, de resabios franceses. Este ciclo épico sería, en nuestra opinión, un epifenómeno del programa ideológico de los monjes cluniacenses tal y como este es reflejado en el rico ciclo historiográfico que hemos analizado. 


\begin{abstract}
RÉSUMÉ
Cet article s'inscrit dans le contexte d'une recherche exhaustive sur la conception de la royauté dans la Castille des XIe et XIIIe siècles qui prête attention au paradigme politique de la Sagesse monarchique. Jusqu'ici très peu étudié. L'étude des chroniques clunisiennes du XIIe siècle apporte dans cette perspective deux elements de conclusion au bilan de la pensée politique dans la Castille médiévale. En premier lieu, elle souligne l'importance des récits historiographiques comme sources de l'idéologie politique ainsi que l'a mis en évidence la recherche française pour d'autres espaces. En second lieu, l'étude met en exergue l'existence d'un contre-modèle de royauté, de facture clunisienne et d'inspiration féodalisante et hiérocratique. Ce schéma théorique domine le XIIe siècle et constitue une alternative tant au modèle de royauté isidorien au siècle précédent qu'au la monarchie romaniste du XIIIe siècle. Pour la configuration de ce contre-modèle, l'apparition du genre épique joue en Castille un rôle essentiel.
\end{abstract}

\title{
SUMMARY
}

This article is related to a context of exhaustive research on the concept of Castilian Kingship (XI-XIII centuries) that pays special attention to the politicaltopos of royal Wisdom, an aspect neglected until now. The analysis of Twelfth Century's Cluniac chronicles brings forward two interesting conclusions on the matter of the political thinking in the kingdoms of Castile and Leon. First, we observe the importance of the role played by the chronicles in the difussion of medieval political ideology, something yet proved by French sholars in another countries. In second place, it is outlined the existence of a counter-model of Kingship, composed by Cluniac monks and relying on the principles of Hierocracy and Feudalism. A counter-model that was hegemonic in Castile all along the Twelfth Century, being an alternative so much to the earlier Isidorian one (Eleventh Century) as to the national statecraft characteristic of the Monarchy in the Thirteenth Century. Related to the shape of this Cluniac countermodel, the offspring of the epic genre in Castile played a significant role. 